\title{
The sedimentary record of wet and dry eolian systems in the Cretaceous of Southeast Brazil: stratigraphic and paleogeographic significance
}

\author{
Patricia Colombo Mescolotti ${ }^{*}$ (D), Filipe Giovanini Varejão (D), Lucas Veríssimo Warren ${ }^{1}$ (D), \\ Francisco Sérgio Bernardes Ladeira ${ }^{2}$ (D), Paulo César Fonseca Giannini ${ }^{3}$ (D), Mario Luis Assine ${ }^{1}$ (D)
}

\begin{abstract}
Sedimentologic and stratigraphic studies of paleo-deserts from the Brazilian Cretaceous are of great potential to understand the paleoclimate and paleogeography of Gondwana during its final rifting stage. Herein, we describe and discuss two depositional units characterized by two distinct eolian systems that are bounded by a long-lived unconformity. The Lower Unit (Barremian/Aptian) encompasses a wet eolian system composed of dune, interdunes, and ephemeral alluvial deposits. A continuous paleosol horizon in the upper part of the Lower Unit records dune stabilization and end of eolian accumulation, in a period of climate amelioration possibly in the late Aptian. The stratigraphic gap proposed for the unconformity (Cenomanian to Coniacian) coincides with the Cretaceous Thermal Maximum. The Upper Unit (Santonian?/ Campanian) comprises dune fields of a dry eolian system capped by the Mata da Corda volcanic rocks. Cross stratification dip directions from both eolian systems shows transport towards SSW. Paleo-winds coming from the northeast quadrant reveal that the continental breakup and drifting had little influence on the surface winds in this Gondwana sector. The Upper Cretaceous paleo-winds are coherent with global paleo-circulation models, based on a high-pressure cell over the South Atlantic proto-ocean, favoring desertification in the inner portion of the southwestern Gondwana.
\end{abstract}

KEYWORDS: Areado Group; Eolian systems; Cretaceous paleo-winds; Sanfranciscana Basin.

\section{INTRODUCTION}

Eolian dune fields dominate the desert landscape and are very sensitive to moisture changes and, thus, they commonly record ancient paleoclimatic fluctuations (Sun and Muhs 2007). Desert conditions prevailed in the interior of Gondwana from the Jurassic to the Cretaceous, as recorded in many sedimentary basins of Brazil. The Jurassic eolian successions include Sanga do Cabral (Nowatzki and Kern 2000) and Guará (Scherer and Lavina 2006) formations of the Paraná Basin, and part of the deposits of Mosquito (Ballén et al. 2013) and Sergi (Kuchle et al. 2011) formations from Parnaíba and Recôncavo basins, respectively. In terms of the Lower Cretaceous, the vast Botucatu desert of the Paraná Basin (Bigarella and Salamuni 1961, Nowatzki and Kern 2000, Scherer 2000, Scherer and Goldberg 2007) and Três Barras

\footnotetext{
${ }^{1}$ Instituto de Geociências e Ciências Exatas, Universidade Estadual Paulista - Rio Claro (SP), Brazil.

E-mails: pamescolotti@outlook.com; filipe.varejao@hotmail.com, lucas.warren@unesp.br; mario.assine@unesp.br

${ }^{2}$ Instituto de Geociências, Universidade Estadual de Campinas Campinas (SP), Brazil. E-mail: ladeira@unicamp.br

${ }^{3}$ Instituto de Geociências, Universidade de São Paulo - São Paulo (SP) Brazil. E-mail: pcgianni@usp.br

${ }^{*}$ Corresponding author
}

Formation of Sanfranciscana Basin (Campos and Dardenne 1997a, Sgarbi 2000, Sgarbi et al. 2001) stand out. The Caiuá desert (Bauru Group) from the Paraná Basin (Fernandes and Ribeiro 2015), as well as coeval successions in the Parecis and Sanfranciscana basins (Batezelli and Ladeira 2016), are also strong pieces of evidence that pronounced aridity prevailed in the central-southern Brazil during the Late Cretaceous.

Desertification of Gondwana inner parts since the Jurassic is also recorded by the Etjo Formation in Namibia (Mountney et al. 1999) and by the abundant eolian deposits in the back arc Neuquén Basin, in western Argentina (Howell et al. 2005, Strömbäck et al. 2005, Veiga and Spalletti 2007), among which the Avilé Member of the Agrio Formation stands out (Veiga et al. 2002).

The Lower Cretaceous of Southeastern Brazilian basins is marked by the dominance of basic volcanic rocks, both in the interior of the Paraná Basin and in the marginal basins of Santos, Campos and Espírito Santo (Almeida et al. 1996, Moreira et al. 2005). The early Cretaceous (Barremian-Aptian) sequence of the Sanfranciscana Basin is the only sedimentary record of the early Cretaceous predating the rupture of Gondwana, which is known in south-central Brazil apart from the rift basins on the Brazilian eastern margin.

Considering this scenario, this work presents a detailed characterization of the eolian systems of Três Barras Formation, in Sanfranciscana Basin, particularly focusing on the sedimentary facies and their associations, definition of regional 
stratigraphic bounding surfaces, and paleo-wind directions. Data were obtained on field (five vertical stratigraphic sections and 632 dip direction of cross-strata were measured) and through a petrographic study ( 15 thin sections). Paleosols were interpreted considering physical and biological processes that occurred during their formation, using the protocol presented by the NRCS (Schoeneberger et al. 2012).

The Sanfranciscana Basin is a vast expanse of well-preserved, but unexplored, desert deposits, as eolian dunes, interdunes, and paleosols. This work is the first detailed study of Três Barras Formation, which provides new light on the discussion of the atmospheric circulation pattern during the Cretaceous and the desertification process that took place in the dawn of South America continent during and after the Gondwana breakup.

\section{GEOLOGICAL SETTING}

The Sanfranciscana Basin is an interior Phanerozoic basin developed in São Francisco Craton (Campos and Dardenne $1997 \mathrm{a})$ that covers an area of approximately $220,000 \mathrm{~km}^{2}$ (Sgarbi et al. 2001) and encompasses the Abaeté (south) and Urucuia (north) sub-basins (Campos and Dardenne 1997b). The study presented here was developed in Abaeté sub-basin (Minas Gerais State), whose stratigraphy includes the Santa Fé (Permian-Carboniferous), Areado (Lower Cretaceous), and Mata da Corda (Upper Cretaceous) groups (Fig. 1). The Lower Cretaceous Areado Group comprises the Abaeté, Quiricó, and Três Barras formations, from base to top (Fig. 1; Campos and Dardenne 1997a, Sgarbi 2000).
The Três Barras Formation is dominantly composed of eolian sandstones with subordinate fluvial deposits (Campos and Dardenne 1997a). These sandstone beds interfinger and conformably overlie the deposits of Quiricó Formation, which is composed mainly of fine-grained lacustrine facies and secondarily by interbedded sandstones of fluvial and eolian origins. Although the shales of Quiricó Formation can be dark gray and organic-rich locally, recording permanent dysoxic/anoxic environments, most of the succession is characterized by mudstones with scattered grains of fine sand and heterolithic facies, desiccation cracks, interpreted as ephemeral shallow water bodies with frequent events of subaerial exposure. The lacustrine facies of Quiricó Formation are dated as Barremian to Aptian, based on ostracod data (Carmo et al. 2004) and early Aptian according to its palynologic content (Lima 1979, Arai et al. 1995).

Três Barras Formation oversteps the limits of the subjacent lacustrine deposits and rests directly on Precambrian rocks, reaching a maximum thickness of $150 \mathrm{~m}$. This unit is overlain by the Upper Cretaceous Mata da Corda Group, whose volcanic alkaline rocks have yielded $\mathrm{U}-\mathrm{Pb}$ isotopic median ages of $80 \mathrm{Ma}$ (Sgarbi et al. 2004).

\section{SEDIMENTARY FACIES AND STRATIGRAPHIC UNITS}

Ten sedimentary facies were recognized in Três Barras Formation, including: medium- to coarse-grained trough
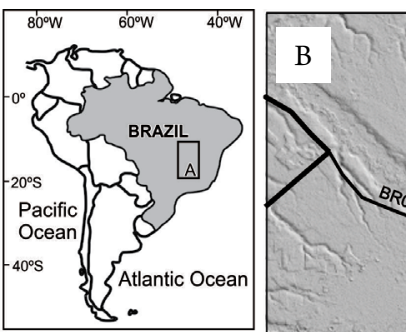

\section{$100^{\circ} 20^{1}$}

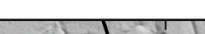

\section{(c)}
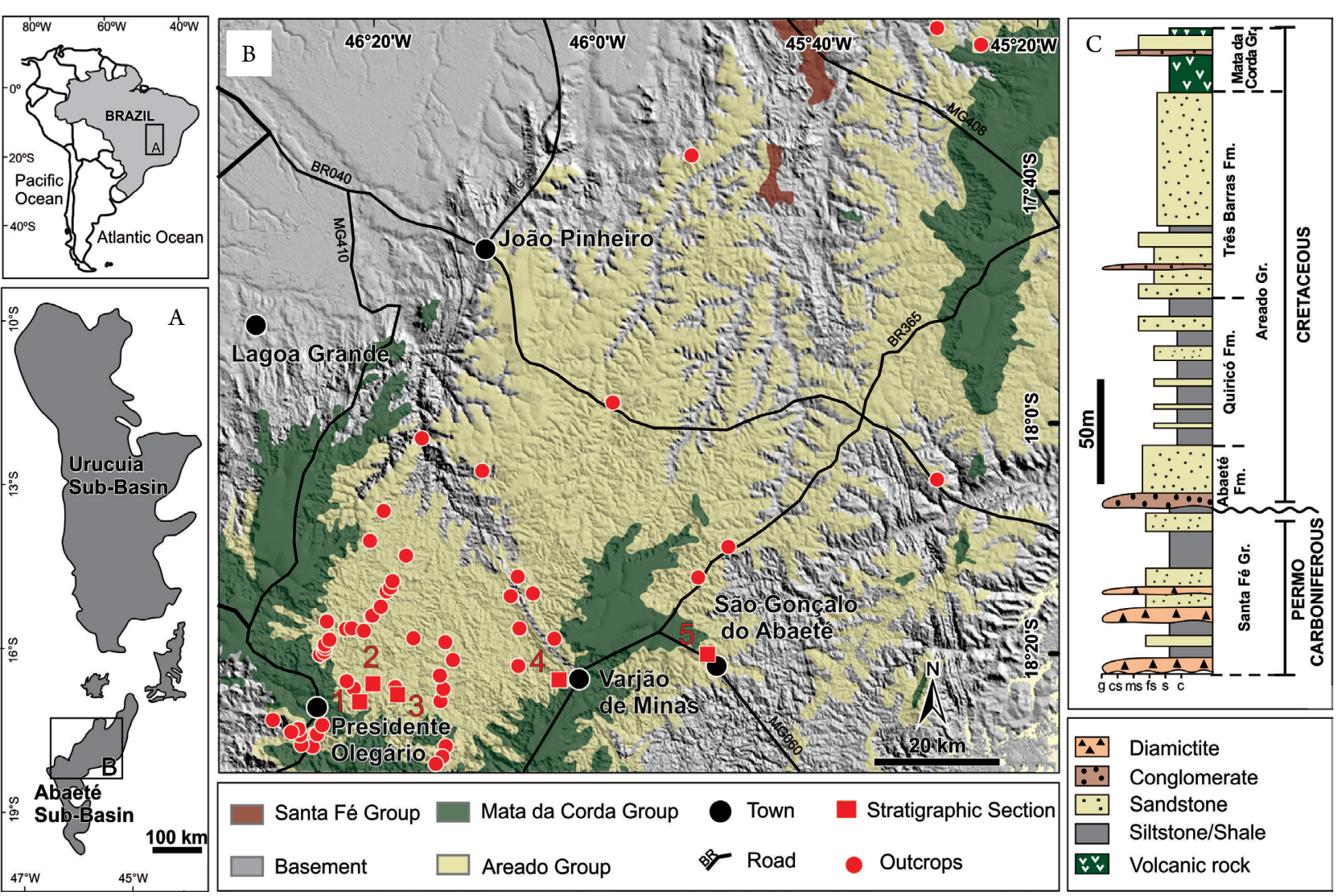

Figure 1. Location of the studied area. (A) Indication of the studied area within Abaeté Sub-Basin, Sanfranciscana Basin; (B) Geological map above STRM with the location of the analyzed outcrops and measured columnar sections (modified from CPRM, 2006); (C) Lithostratigraphic column of Abaeté Sub-Basin, Sanfranciscana Basin, after Campos and Dardenne (1997a). 
cross-bedded sandstone (St1); meter-scale trough cross-bedded sandstone (St2); planar cross-bedded sandstone (Sp); parallel-laminated sandstone (Sl); climbing ripple cross-laminated sandstone $(\mathrm{Sr})$; sandstone with deformational structures $(\mathrm{Sd})$; paleosol $(\mathrm{P})$; massive mudstone $(\mathrm{Fm})$; laminated mudstone $(\mathrm{Fl})$; and interlaminated fine-grained sandstones and mudstones with heterolithic lamination $(\mathrm{H})$. A more detailed description of the sedimentary facies and process interpretation is presented in Table 1 .

Facies St 1 corresponds to medium- to coarse-grained trough cross-bedded sandstones, poorly selected with muddy rip-up clasts, displaying lenticular to channelized beds (0.1- to 1.5-m-thick; Figs. 2A and 3A). It is interpreted as a result from the migration of tridimensional subaqueous dunes (Tab. 1).

St 2 is the most common facies in the studied successions and consists of red, fine- to medium-grained sandstone trough cross-bedded disposed in lens-shaped sets (Fig. 2B and 2C), forming up to 20-m-thick cosets. Foresets of St 2 are marked by bimodal grain size segregation and pin stripe lamination (sensu Fryberger and Schenk 1988, Fig. 2D), and mm-thick lenses showing inverse grading. The $\mathrm{Sp}$ facies differs from St2 by the tabular geometry of cross strata set, i.e. the apparent absence of festoon shape in both transverse and plan views of the sets. The foresets of $S p$ are characterized by grain size segregation and pin stripe lamination, including up to $0.3-\mathrm{m}$-thick discontinuous lenses with inverse grading more abundant in the middle parts of foresets (Fig. 2E). The St 2 and Sp facies are attributed to the migration of eolian dunes in view of the largescale cross-bedding, with pin stripe lamination and inversely graded thin lenses (Tab. 1).

Facies Sl comprises fine- to medium-grained parallel-laminated sandstones with two-fold grain-size segregation, arranged in 0.5 - to 2-m-thick horizontal to low angle (less than $5^{\circ}$ ) strata (Fig. 2F). Isolated thin sets (cm-to dm-thick) of fineto coarse-grained sandstones (St 1$)$ can occur interbedded between Sl facies (Fig. 3A). Sr facies is characterized by fine- to medium-grained sandstones with subcritical to critical climbing ripples. This is interpreted as a result from the migration of subaqueous ripples (Tab. 1). Sandstone with deformation structures (Sd facies; Fig. 3B) appears as dm- to m-thick tabular beds of red colored, fine- to medium-grained sandstones, presenting $\mathrm{cm}$ - to $\mathrm{dm}$-scale disharmonious folds, fluid escape pillars, and irregular sand dikes.

The heterolithic facies $(\mathrm{H})$ is composed of interlaminated fine-grained sandstones and mudstones, with soft-sediment deformation features locally (crinkly bedding, Figs. 3C and 3D). Laminated grey mudstone facies ( $\mathrm{Fl}$ ) occurs as up to 0.5-m-thick tabular or lenticular beds, showing recurrent mud cracks. Red, massive mudstone facies (Fm) consists of laterally discontinuous horizontal strata with lenticular geometry and variable thickness (up to $20 \mathrm{~m}$; Figs. 3E and $3 G)$. These facies commonly include scattered fine-grained quartz in the rock matrix. The processes interpreted for these facies are alternation of flow and decantation $(\mathrm{H})$, and decantation with $(\mathrm{Fl})$ or without $(\mathrm{Fm})$ evidence of subaerial desiccation (Tab. 1).
The facies $\mathrm{P}$ (paleosols) is identified by its red-to-purple color and consists originally of sandstones facies, in which relicts of the original stratification are locally preserved. The sedimentary structures are obliterated due to intense mottling regarding localized cementation in the form of white carbonate spots, nodules and concretions, including rhizo-concretions (Figs. 3H-3J). Vertical root traces ranging in size from 2 to $6 \mathrm{~cm}$ may be recognized in less mottled profiles, as well as invertebrate trace fossils compatible with feeding habits (fodinichnia). The group of characteristics described in this facies (Tab. 1) points to their characterization as a paleosol. The depth and grade of pedogenesis vary spatially and along the sedimentary succession studied, according to the type of previous deposit on which it has been developed.

The facies $\mathrm{P}$ is observed in all measured vertical columnar sections at several stratigraphic levels, revealing a similar stacking pattern in the studied area (Fig. 4). Paleosol horizons are usually $\mathrm{cm}$ - to $\mathrm{dm}$-thick and laterally restrict. The exception is a unique paleosol horizon up to 15 -m-thick with great lateral continuity (tens of kilometers), which is easy to track and can be considered a stratigraphic guide bed of the entire study area (Fig. 5).

Paleosols with great geographic extent can be deemed important stratigraphic markers in many eolian and fluvial depositional systems (Meyer 1987, Schirmer 1999, Retallack 2001, Atchley et al. 2013). In the case of Três Barras Formation, the above described lateral continuous paleosol is commonly incomplete, without the A horizon and upper levels of the $\mathrm{B}$ horizon, which shows the presence of a sub-horizontal planar erosive surface on its top. This surface can be tracked throughout the escarpment that surrounds the plateau where the Três Barras Formation is best exposed. Thus, the paleosol top is considered the datum for stratigraphic correlations and the regional boundary that divides the sedimentary succession into two distinct stratigraphic units (lower and upper units) (Fig. 4).

\section{LOWER UNIT}

The up to 70-m-thick lower unit interfingers and conformably overlies the deposits of Quiricó Formation, which is bounded in its upper part by the regional planar erosive surface. This unit is characterized by great lateral and vertical variation of facies and recurrence of paleosol horizons. In general, the $\mathrm{St}_{2}$ facies prevails in the entire succession that occurs interbedded with other sandstone facies $\left(\mathrm{Sl}, \mathrm{Sr}, \mathrm{St}_{1}\right)$, as well as with heterolithic $(\mathrm{H})$ and mudstone facies (Fm and $\mathrm{Fl}$ ). In the upper part of this unit, these facies transition (or locally pass abruptly) upwards into the paleosol horizon recognized in all the study area.

Petrographic microscope analysis of $\mathrm{St}_{2}$ and $\mathrm{Sl}$ facies in the lower stratigraphic unit revealed the predominance of subrounded to rounded grains, with major occurrence of quartz $(85 \%)$, and secondarily, feldspar (10\%) and lithic fragments (5\%; polycrystalline quartz). The arenites of both facies contain up to $20 \%$ of calcite cement, and its loose framework packing 
Table 1. Description of sedimentary facies recognized in Três Barras Formation and interpretation of processes.

\begin{tabular}{|c|c|c|c|c|}
\hline Code & Facies & Diagnostic features & Other features & Process interpretation \\
\hline $\mathrm{Fl}$ & $\begin{array}{l}\text { Laminated } \\
\text { mudstone }\end{array}$ & $\begin{array}{l}\text { Grey colored, fine-grained mudstone, } \\
\text { with fine (mm-thick) lamination, in up } \\
\text { to } 5 \text {-dm-thick tabular or lenticular beds. }\end{array}$ & $\begin{array}{l}\text { Recurrence of mud cracks. Occasional } \\
\text { presence of fossils (palynomorphs, } \\
\text { ostracod, clam shrimps, fish and } \\
\text { dinosaurs) and evaporite } \\
\text { (gypsum pseudomorphs). }\end{array}$ & $\begin{array}{l}\text { Mud deposition by decantation in } \\
\text { standing waters without effect of } \\
\text { bottom currents or wave orbitals. } \\
\text { Common subaerial exposure. }\end{array}$ \\
\hline $\mathrm{Fm}$ & $\begin{array}{l}\text { Massive } \\
\text { mudstone }\end{array}$ & $\begin{array}{l}\text { Red colored massive mudstones } \\
\text { with scattered grains of fine sand in } \\
\text { lenticular beds of variable thicknesses } \\
\text { (centimeters up to 1-m-scale). }\end{array}$ & $\begin{array}{l}\text { Common bioturbation, sometimes as } \\
\text { up to } 10 \text {-cm-long vertical/oblique tubes } \\
\text { with preserved meniscus (spreiten) } \\
\text { (Taenidium barretti). Recurrence of up } \\
\text { to } 20 \text {-cm-deep mud cracks. }\end{array}$ & $\begin{array}{l}\text { Mud deposition by decantation in } \\
\text { standing waters without effect of } \\
\text { bottom currents or wave orbitals, } \\
\text { accompanied by wind-blown sand } \\
\text { grains. Common subaerial exposure. }\end{array}$ \\
\hline $\mathrm{H}$ & Heterolithic & $\begin{array}{l}\text { Dm-thick tabular beds of interlaminated } \\
\text { fine-grained sandstones and mudstones, } \\
\text { with small-scale ripple cross-lamination } \\
\text { in the sandstone lenses and variable } \\
\text { proportions of sand/mud: } 2: 1 \text { (flaser), } \\
1: 1 \text { (wavy) and } 1: 2 \text { (linsen). }\end{array}$ & $\begin{array}{l}\text { Common desiccation cracks in } \\
\text { the mudstone laminae. Common } \\
\text { bioturbation characterized by 5-cm- } \\
\text { long vertical and/or oblique tubes } \\
\text { with meniscus (Taenidium barretti). } \\
\text { Recurrence of wavy bedding, } \\
\text { locally with soft-sediment } \\
\text { deformation features. }\end{array}$ & $\begin{array}{l}\text { Alternation of flow and decantation } \\
\text { in subaqueous conditions. Highly } \\
\text { variable moisture and water table } \\
\text { oscillation with prolonged periods of } \\
\text { dryness and subaerial exposition. }\end{array}$ \\
\hline $\mathrm{P}$ & Paleosol & $\begin{array}{l}\text { Light red to purple colored, fine- to } \\
\text { medium-grained, structureless } \\
\text { sandstones organized in meter-thick } \\
\text { tabular beds with carbonate spots, } \\
\text { concretions and nodules, as well } \\
\text { as mottling zones and/or stained } \\
\text { horizons with occasional presence } \\
\text { of manganese oxide-hydroxide veins } \\
\text { or layers. Common presence of } \\
\text { vertical/oblique tubes with meniscus } \\
\text { (Taenidium barretti), } 2 \text { - to 6-cm- } \\
\text { long root marks, and recurrence of } \\
\text { rhizoliths associated with precipitation } \\
\text { of calcium carbonates. }\end{array}$ & $\begin{array}{l}\text { Occasional relicts of the original } \\
\text { stratification, with lateral variation of } \\
\text { depth and intensity of obliteration. }\end{array}$ & $\begin{array}{l}\text { Obliteration of primary structures due } \\
\text { to pedogenesis, under reducing and } \\
\text { hydromorphic conditions, as indicated } \\
\text { by the color purple, presence of layers } \\
\text { rich in manganese oxide-hydroxide } \\
\text { and abundant bioturbation. }\end{array}$ \\
\hline $\mathrm{Sd}$ & $\begin{array}{l}\text { Sandstone with } \\
\text { deformational } \\
\text { structures }\end{array}$ & $\begin{array}{l}\text { Red colored, fine- to medium-grained, } \\
\text { silicified sandstones organized in } \\
\text { tabular beds (dm-to m-thick) with } \mathrm{cm} \text { - } \\
\text { to } \mathrm{dm} \text {-scale disharmonious folds, fluid } \\
\text { escape pillars, and punctual irregular } \\
\text { injected sand dikes. }\end{array}$ & $\begin{array}{l}\text { Subordinated presence of structures } \\
\text { indicating brittle deformation, such } \\
\text { as small-scale normal and reverse } \\
\text { faults, and drag folds. Up to 3-m-scale } \\
\text { pyroclasts locally associated with trough } \\
\text { cross-bedded and deformed sandstones. }\end{array}$ & $\begin{array}{l}\text { Soft-sediment deformation by } \\
\text { liquefaction and fluidization, including } \\
\text { sand dikes injection. Reddening } \\
\text { of sediments affected by high } \\
\text { temperature bombs and lapilli. }\end{array}$ \\
\hline $\mathrm{Sp}$ & $\begin{array}{l}\text { Planar } \\
\text { cross-bedded } \\
\text { sandstone }\end{array}$ & $\begin{array}{l}\text { Light red colored, fine to medium- } \\
\text { grained sandstones, marked by grain size } \\
\text { segregation and pin stripe lamination; } \\
\text { occasional lenses of sand inversely } \\
\text { graded and ripple cross-lamination. Up } \\
\text { to } 15 \text {-m-thick tabular and lens-shaped } \\
\text { sets with planar cross-stratification. }\end{array}$ & $\begin{array}{l}\text { Well-sorted, rounded, and non- } \\
\text { cemented quartz grains, with rare } \\
\text { vestiges of partially or completely } \\
\text { weathered feldspar. Cm- to } \\
\text { dm-scale pyroclast bodies } \\
\text { disrupting stratification. }\end{array}$ & $\begin{array}{l}\text { Migration of large transverse dunes } \\
\text { due to wind action under high } \\
\text { sedimentation rate, probably with } \\
\text { enormous sediment supply. An } \\
\text { alternative hypothesis is migration of } \\
\text { very large sinuous-crested eolian dunes, } \\
\text { whose trough pattern of cross strata is } \\
\text { not observable in the outcrop scale. }\end{array}$ \\
\hline Sl & $\begin{array}{l}\text { Parallel- } \\
\text { laminated } \\
\text { sandstone }\end{array}$ & $\begin{array}{l}\text { Fine- to medium-grained parallel- } \\
\text { laminated sandstones with two-fold } \\
\text { grain size segregation, arranged in } 0.5 \text { - } \\
\text { to } 2 \text {-m-thick horizontal to low angle } \\
\quad\left(\text { less than } 5^{\circ}\right) \text { strata. }\end{array}$ & $\begin{array}{l}\text { Rounded calcium carbonate clasts } \\
\text { (granule- and pebble-sized) common at } \\
\text { the base of sets. }\end{array}$ & $\begin{array}{l}\text { Protodunes migration across deflation } \\
\text { sand flats under high ratio of wind } \\
\text { velocity/sedimentary supply. }\end{array}$ \\
\hline $\mathrm{Sr}$ & $\begin{array}{l}\text { Climbing ripple } \\
\text { cross-laminated } \\
\text { sandstone }\end{array}$ & $\begin{array}{l}\text { Fine- to medium-grained sandstones } \\
\text { organized in cm-thick lenticular beds } \\
\text { with climbing ripple cross-lamination. }\end{array}$ & $\begin{array}{l}\text { Common bioturbation characterized } \\
\text { by vertical and/or oblique tubes } \\
\text { with meniscus (spreiten) of variable } \\
\text { thickness ( } 0.5 \text { - to } 5 \text {-cm-thick) } \\
\text { (Taenidium barretti). }\end{array}$ & $\begin{array}{l}\text { Migration of subaqueous ripples in } \\
\text { lower flow regime. }\end{array}$ \\
\hline $\mathrm{St}_{1}$ & $\begin{array}{l}\text { Medium- to } \\
\text { coarse-grained, } \\
\text { trough } \\
\text { cross-bedded } \\
\text { sandstone }\end{array}$ & $\begin{array}{l}\text { Medium- to coarse-grained sandstones, } \\
\text { moderately to poorly selected, } \\
\text { frequently containing granules and } \\
\text { pebbles. Lenticular to channelized } \\
\text { beds ( } 0.1 \text { - to } 1.5 \text {-m-thick), commonly } \\
\text { exhibiting erosive base and sharp top } \\
\text { organized in dm-scale finning-upward } \\
\text { sets with trough cross-stratification. }\end{array}$ & $\begin{array}{l}\text { Rounded mud (rip-up) and calcium } \\
\text { carbonate intraclasts (granules and } \\
\text { pebbles) common at base of sets. }\end{array}$ & $\begin{array}{l}\text { Migration of three-dimensional } \\
\text { subaqueous dunes by the action of } \\
\text { unidirectional currents under lower } \\
\text { flow regime, with intraclasts from } \\
\text { erosion and reworking of other facies. }\end{array}$ \\
\hline $\mathrm{St}_{2}$ & $\begin{array}{l}\text { Meter-scale } \\
\text { trough } \\
\text { cross-bedded } \\
\text { sandstone }\end{array}$ & $\begin{array}{l}\text { Cream to red colored, fine- to medium- } \\
\text { grained sandstones. Foresets marked by } \\
\text { grain size segregation with differential } \\
\text { cementation (pin stripe lamination) } \\
\text { and inversely graded thin lenses. Lens- } \\
\text { shaped sets (1- to 10-m-thick) with } \\
\text { trough cross-stratification. }\end{array}$ & $\begin{array}{l}\text { Small-scale deformation features (e.g. } \\
\text { disharmonious folds and fluid escape } \\
\text { structures) at the base of some foresets. } \\
\text { Cm- to dm-thick mottled sandstones, } \\
\text { with relict of the original stratification } \\
\text { and occasionally preserved root traces } \\
\text { on the top of sets. Sub-rounded caliche } \\
\text { granules and pebbles at foresets and at } \\
\text { base of sets. }\end{array}$ & $\begin{array}{l}\text { Migration of large sinuous-crested } \\
\text { eolian dunes (barchans and/or } \\
\text { barchanoid chains), sometimes } \\
\text { with sand liquefaction at the base of } \\
\text { foresets due to gravitational instability. }\end{array}$ \\
\hline
\end{tabular}


indicates early cementation, probably during the eodiagenetic stage (Figs. 6A and 6B).

The paleocurrents measured in foresets of trough-cross bedded sandstones from the $\mathrm{St}_{2}$ facies indicate a bedform migration and, thus, a main sedimentary transport towards south and southwest (Fig. 4).

\section{Facies association}

In the Lower Unit, the dune deposits ( $\mathrm{St}_{2}$ facies) occasionally exhibit small-scale soft-sediment deformation features (disharmonious folds and fluid escape structures) and carbonate clasts at the base of eolian foresets (Fig. 3I). Considering the paleocurrent pattern found in this unit (Fig. 4), which is characterized by medium dispersion (57\%) and unidirectional dip (sensu McKee 1979), as well as the geometry and dimensions of sedimentary structures, this facies can be interpreted as produced by migration of sinuous-crested eolian dunes (barchans and/or barchanoid chains), as seen in Table 1.

Considering a dune-field depositional setting, the other sedimentary facies ( $\mathrm{Sl}, \mathrm{Sr}, \mathrm{St}_{1}, \mathrm{H}, \mathrm{Fm}$ and $\mathrm{Fl}$ ) that appear interbedded with $\mathrm{St}_{2}$ sets or cosets correspond to interdune facies (Hunter 1981, Kocurek 1981). Hence, the Sr, Fm and Fl facies (Fig. 7) are interpreted as subaqueous deposits formed in small lakes developed in interdune areas during the seasonal flooding (Langford 1989, Langford and Chan 1989, Mountney and Thompson 2002, Tab. 1). Nevertheless, the $\mathrm{Sl}$ facies is interpreted as produced by the migration of proto-dunes in deflation areas under high ratio of wind velocity/sedimentary supply. Despite the usual interpretation of parallel-laminated sandstones as typical of sandsheet deposits (Kocurek and Nielson 1986), in the present case, this facies is interpreted as formed in interdune areas due to: its intimate association with $\mathrm{St}_{2}$ dune facies; restricted thickness (less than $2 \mathrm{~m}$ ) and continuity; and frequent presence of granules and pebbles, including carbonate intra-clasts (Fig. 3J)

The recurrence of of mega-ripples facies $\mathrm{St}_{1}$ (Figs. 2A) locally with ripped-up mud clasts on foresets suggests fluvio-eolian interaction and deposition of alluvial deposits in the wet interdune region (Bristow and Mountney 2013).
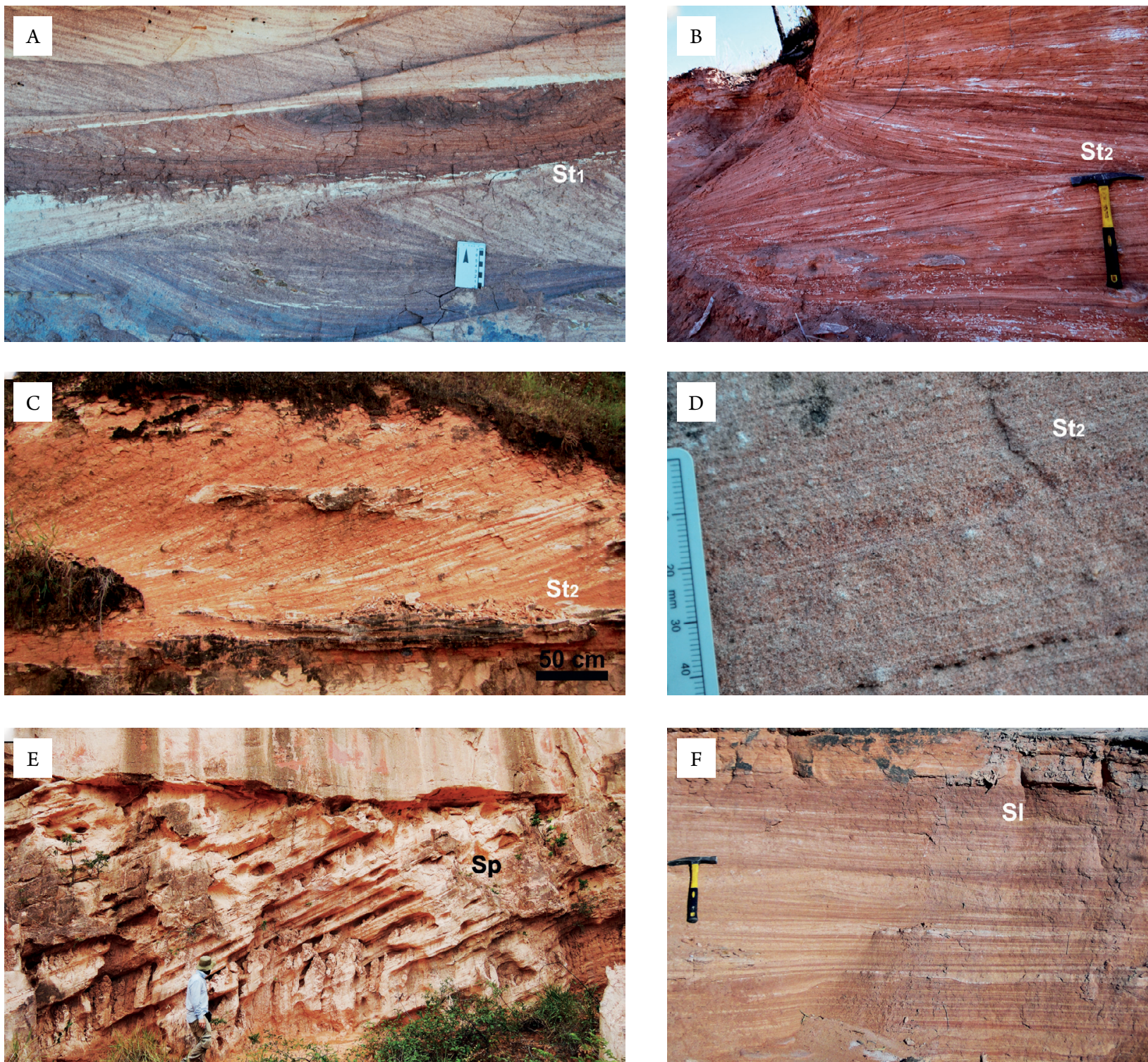

Figure 2. Sedimentary facies from the lower unit of Três Barras Formation. (A) Medium- to coarse-grained, trough cross-bedded sandstone (St1); (B-C): Meter-scale trough cross-bedded sandstone (St2); (D) Grain-flow lenses with inverse grading in St2 facies; (E) Planar crossbedded sandstone (Sp); (F) Parallel-laminated sandstones (Sl). Scale in A and D is 8-cm-long; hammer in B and F is 25-cm-long. 
The ephemeral flash flood events responsible for the $\mathrm{St}_{1}$ deposition could have promoted erosion of dune sands, carbonate nodules from paleosols and interdune mud deposits, carrying these nodules and mud intra-clasts into the interdune area. Afterwards, deflation processes concentrated these intra-clasts forming lag deposits, which are later buried by migrating eolian dunes or proto-dunes $\left(\mathrm{St}_{2}\right.$ or Sl facies, respectively; Figs. 3I and 3J). This explains the presence of carbonate clasts at the sub-horizontal limits of sets in the $\mathrm{St}_{2}$ and $\mathrm{Sl}$ facies.
$\mathrm{H}$ facies is attributed to alternation of subaqueous flow and decantation (Tab. 1), in marginal parts of ephemeral drainages or interdune lakes submitted to temporary and recurrent agitation by wind-generate currents or waves.

The interdune deposits of the Lower Unit typically show frequent lateral and vertical facies changes because of water table fluctuation and variable sand input transported by winds. The presence of several beds of the Fl, Fm and $\mathrm{H}$ facies with desiccation cracks indicates flooding events alternating with subaerial exposition (Fig. 7). Burrows assigned
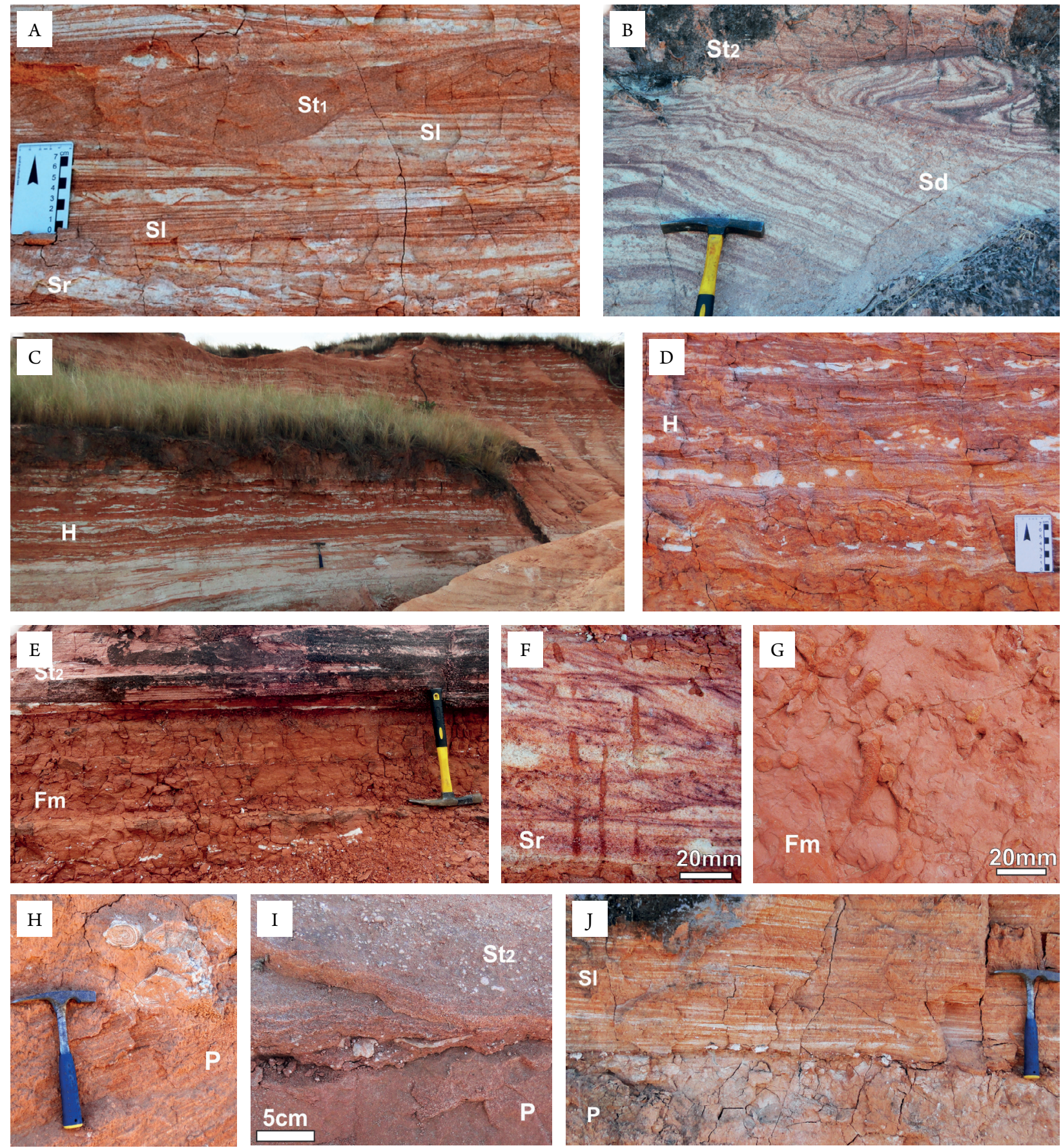

Figure 3. Sedimentary facies of the lower unit of Três Barras Formation. (A) Centimeter- to dm-thick sets of fine- to coarse-grained sandstones with trough cross stratification ( $\mathrm{St}_{1}$ - subaqueous dunes) interspersed in the laminated sandstones ( $\mathrm{Sl}$ ); (B) Soft-sediment deformation in sandstone (Sd) associated with cross-stratified sandstone (St2); (C) Meter-thick deposits dominated by heterolithic facies (H); (D) Wavy to crinkly bedding and ripple cross-lamination in the sandstone lenses in heterolithic facies $(\mathrm{H})$; (E) Red colored massive mudstone (Fm); (F-G) Burrows affecting Sr and Fm facies; (H) Carbonate rhizolith in paleosol facies (P); (I) Carbonate clasts in cross-bedded sandstones (St2) overlying carbonate-rich paleosols; (J) Lag deposits composed of carbonate clasts separating paleosol (P) from overlying horizontally laminated sandstones (Sh). Scale in A and D is 8-cm-long; hammers in B, C, E, H and I are 25-cm-long. 
to the Taenidium barretti, an ichnogenus from the Scoyenia ichnofacies (Seilacher 1967, Buatois and Mángano 2002), were described in several paleosol beds (P; Fig. 5) and moist interdune facies (Fm, Sr and H; Fig. 3F and 3G). According to the index proposed by Taylor and Goldring (1993), the degree of bioturbation observed in some intervals ranges from low (B2 - with recognizable sparse traces and sedimentary structures) to high (B4 - with high density of traces and sedimentary structures obliterated). In some places, the bioturbation degree was high enough to completely obliterate the original sedimentary structures, giving a massive appearance for sandstones. The predominant occurrence of fodinichnia burrows (Bromley 1996) can be attributed to invertebrates taking advantage of suitable moist areas, where the water table tends to be more superficial (Hasiotis 2002).

Stratigraphic relationships between dunes and wet interdune deposits are well illustrated through an outcrop in Três Barras River valley, which records the migration of eolian dunes into desiccated, but formerly flooded interdune areas (Fig. 7). Dune foresets downlap the exposed bottom surface of small lakes or flood plain of ephemeral rivers in interdune areas, in which mudstones are remarkably disrupted by desiccation cracks up to 0.3 -m-deep filled with eolian sandstone (Fig. 7C and 7D).

The $\mathrm{dm}$-thick paleosols described occur associated with both dune and interdune deposits. In the dune deposits, they appear at the top of the cross sets and are poorly developed, with mottled aspect and partial obliteration of original sedimentary structures attributed to the presence of scarce and small vegetation. The paleosols developed on interdune deposits are poorly developed too and are characterized by purple color and mottled patterns, intense bioturbation (Scoyenia ichnofacies), white carbonate concretions, and obliteration of original sedimentary structures (Fig. $3 \mathrm{H}$ ). As commented, only the paleosol stratigraphically positioned in the top of the Lower Unit succession is considered well-developed, organized in distinct pedogenic horizons (Fig. 5). In most of the paleosol profiles, it is not possible to recognize the nature (dune versus interdune) of the original deposits.

Soft-sediment deformation features with concave-upward and asymmetric protuberances (shaft wall) were not only recognized in interdune facies association (nine outcrops; Figs. 8A-8C), but also in dune and paleosol associations

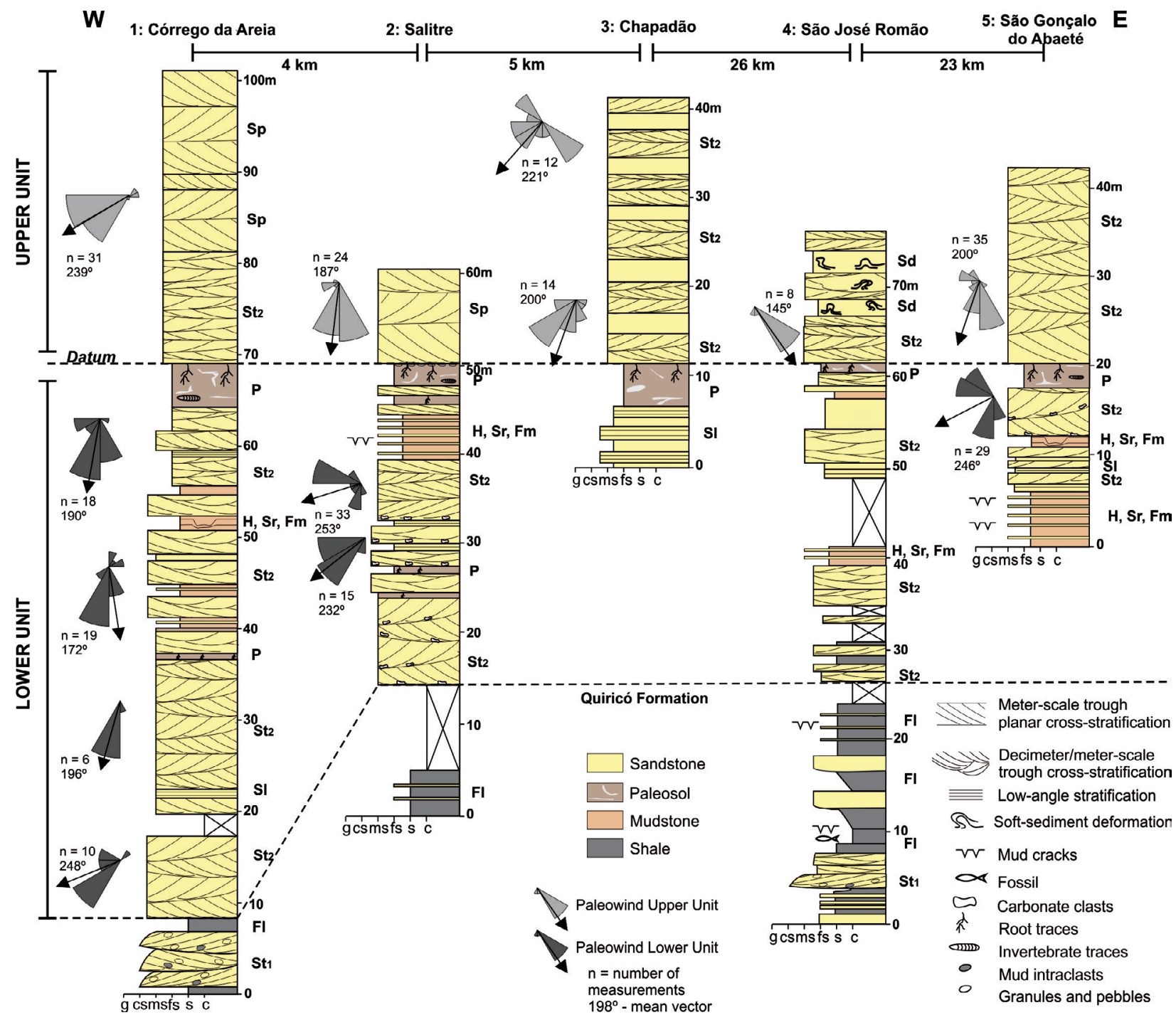

g: gravel; cs: coarse-grained sandstone; ms: medium-grained sandstone; fs: fine-grained sandstone; s: siltstone; c: clay.

Figure 4. Measured stratigraphic vertical profiles. 
(one outcrop each; Fig. 8D). In all cases, the soft-sediment deformation downfolded the original sedimentary structure. Recurrent $\mathrm{cm}$-thick normal faults are described in vertical outcrops, observed in section (Fig. 8). It was not possible to see this deformation in plan-view. The shape and size of these deformational features are compatible with footprints and undertracks (Lockley 1991). The downfolding of the sedimentary structure is typical for dinosaur undertrack
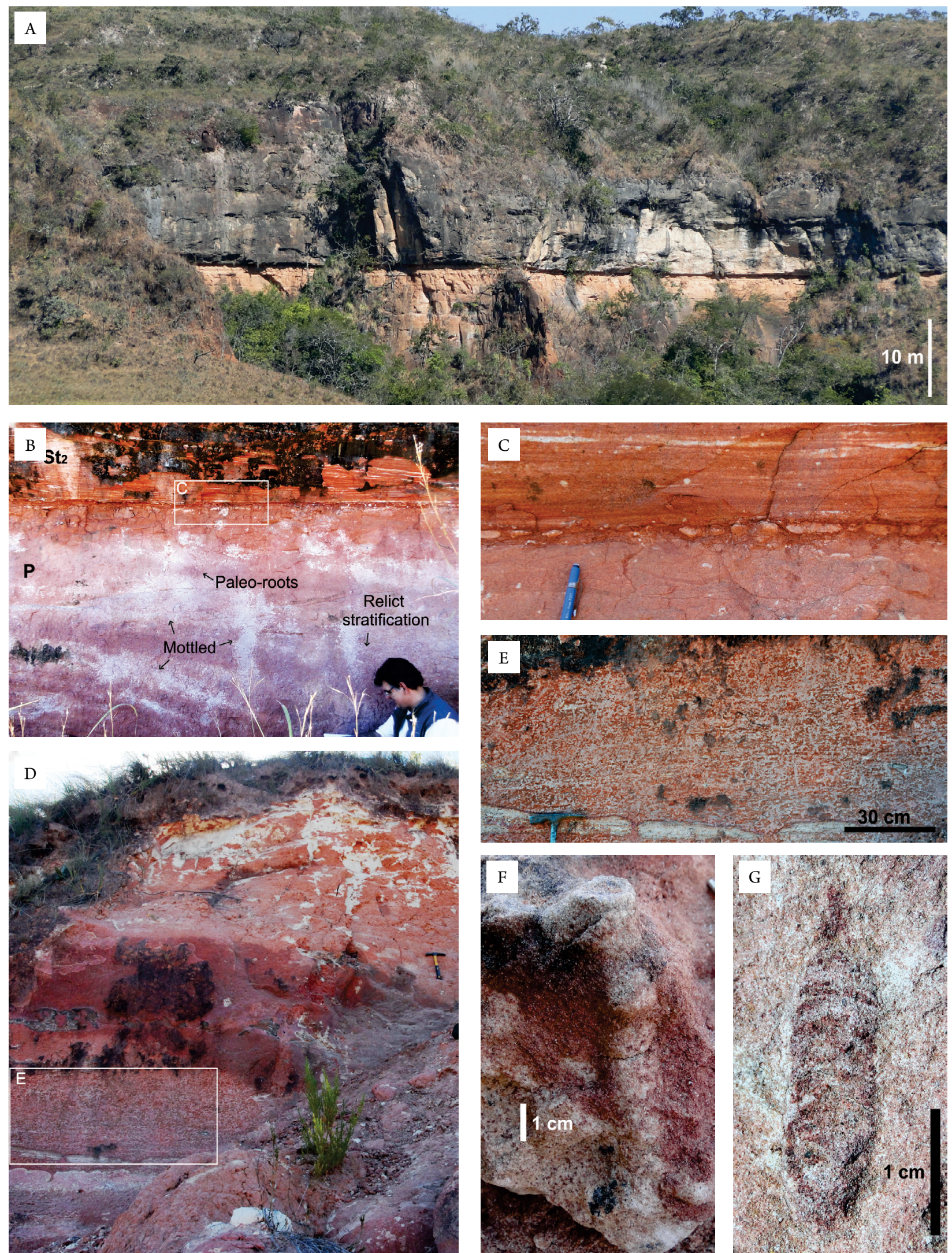

Figure 5. Planar erosive surface between the lower and upper stratigraphic units of Três Barras Formation. (A) The surface is clearly visible in the escarpments; (B) Planar surface cutting the paleosol horizon; (C) Armored lag of carbonate concretions on the top of paleosol; (D-E) Heterogeneous, thick paleosol profile, partially to intensely mottled; (F) Carbonate rhizolith; (G) Taenidium barreti tubes with prominent meniscus in paleosol facies. Pencil in C is 15 -cm-long; hammers in D-E are $25-\mathrm{cm}-$ long. 
and cannot be explained by sedimentary processes (Xing et al. 2015). The diameter of these structures ranges from 60 to $120 \mathrm{~cm}$, and the depth from 18 to $36 \mathrm{~cm}$, while the possible undertracks are up to $0.7-\mathrm{m}$-deep. These putative footprints and undertracks are tentatively interpreted as produced by sauropods, considering the morphology and dimensions of similar occurrences (Dentzien-Dias et al. 2008, Thulborn 2012, Pond et al. 2014) as the comparable sauropod trails that occur in eolian-fluvial strata of Upper Jurassic Guará Formation, Brazil (Scherer and Lavina 2005, Dentzien-Dias et al. 2008). It is important to note that sauropod bones have already been described for the Areado Group (Zaher et al. 2011), and some soft-sediment deformation features had already been interpreted by Carvalho and Kattah (1998) as footprints from celliform theropods and ornithopods.

\section{Wet eolian system}

In general, eolian systems can be classified in three different types (dry, wet, and stabilized), based on the position of the water table in relation to the paleo-depositional surface (Kocurek and Havholm 1993, Bristow and Mountney 2013)
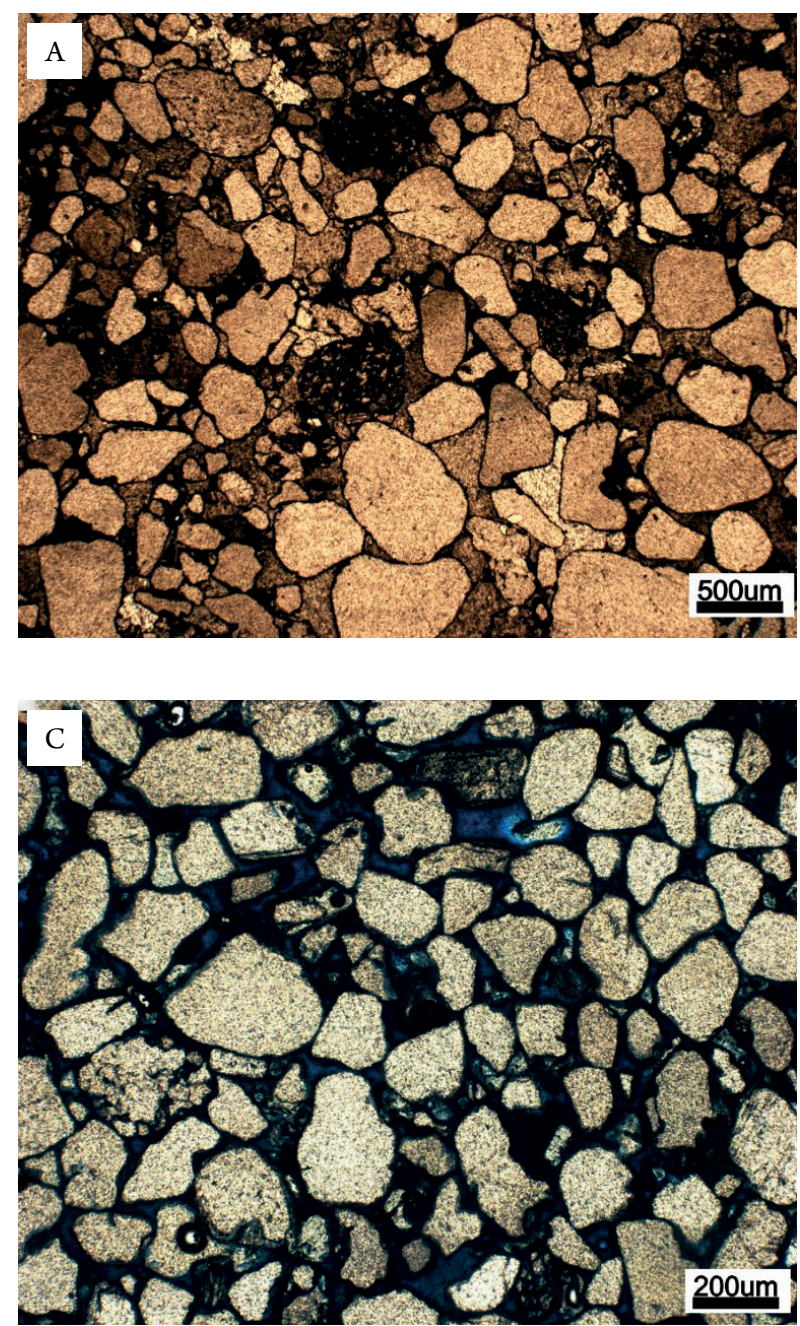

Fd: feldspar; Lt: Lithic fragment; Ca: carbonate.

Figure 6. Petrographic features of sandstones from Três Barras Formation. (A-B) Lower unit sandstones present loose grain framework and pervasive cementation by calcium carbonate; (C-D) Well sorted and mature quartz sandstones of the upper unit presenting high porosity. Photos on the left taken with parallel nicols. On the right, photos were taken with crossed nicols.
The Lower Unit sedimentary record is characterized by a facies association of eolian dunes (St2) and proto-dunes (Sl) alternated with interdune deposits (facies $\mathrm{Sr}, \mathrm{Sl}, \mathrm{H}$, and $\mathrm{Fm}$ ) and ephemeral flash flood deposits ( $\left.\mathrm{St}_{1}, \mathrm{H}, \mathrm{Fm}\right)$. Towards the top of the Lower Unit, the interdunes become more frequent until culminating in an extensive paleosol horizon (facies P).

Typical interdune facies are present, recording a wide variety of sedimentary processes under variable moisture conditions. They are characterized by recurrence of mudstones (facies $\mathrm{Fm}$ and $\mathrm{Fl}$ ) of subaqueous origin, including heterolithic beds and subaqueous ripples (facies $\mathrm{H}$ and $\mathrm{Sr}$, respectively). The occurrence of up to 1.5 -m-thick layers of massive mudstones, with scattered sand grains and levels with desiccation cracks, suggests an occasional existence of short-lived water bodies in the interdune area.

The facies association of the Lower Unit is compatible with a wet eolian system characterized by shallow water table, whose periodic oscillation in interdune areas controlled the eolian accumulation (Fig. 9, Mountney and Thompson 2002, Jones et al. 2016). This interpretation is supported by the presence of poorly developed paleosols and trace fossils that indicate the Scoyenia ichnofacies (Buatois and Mángano 2002),
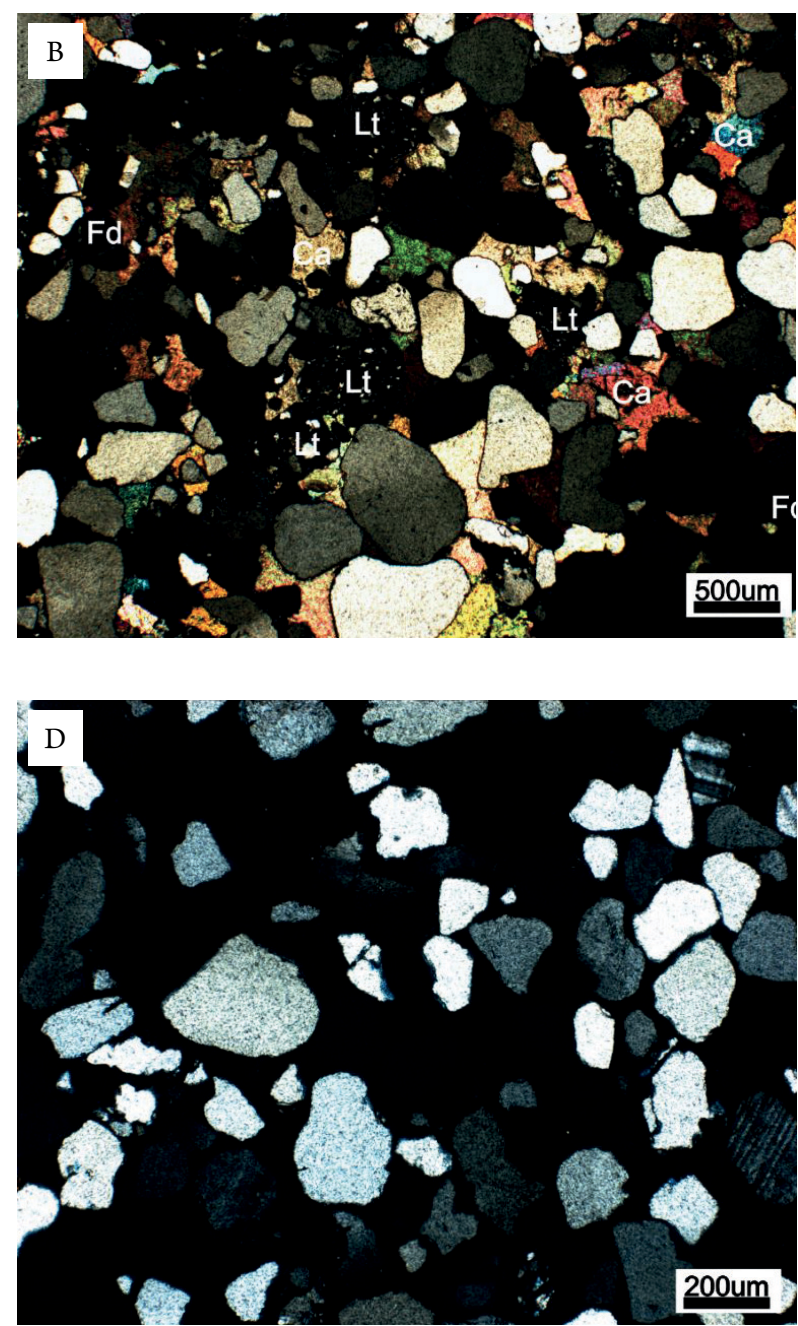

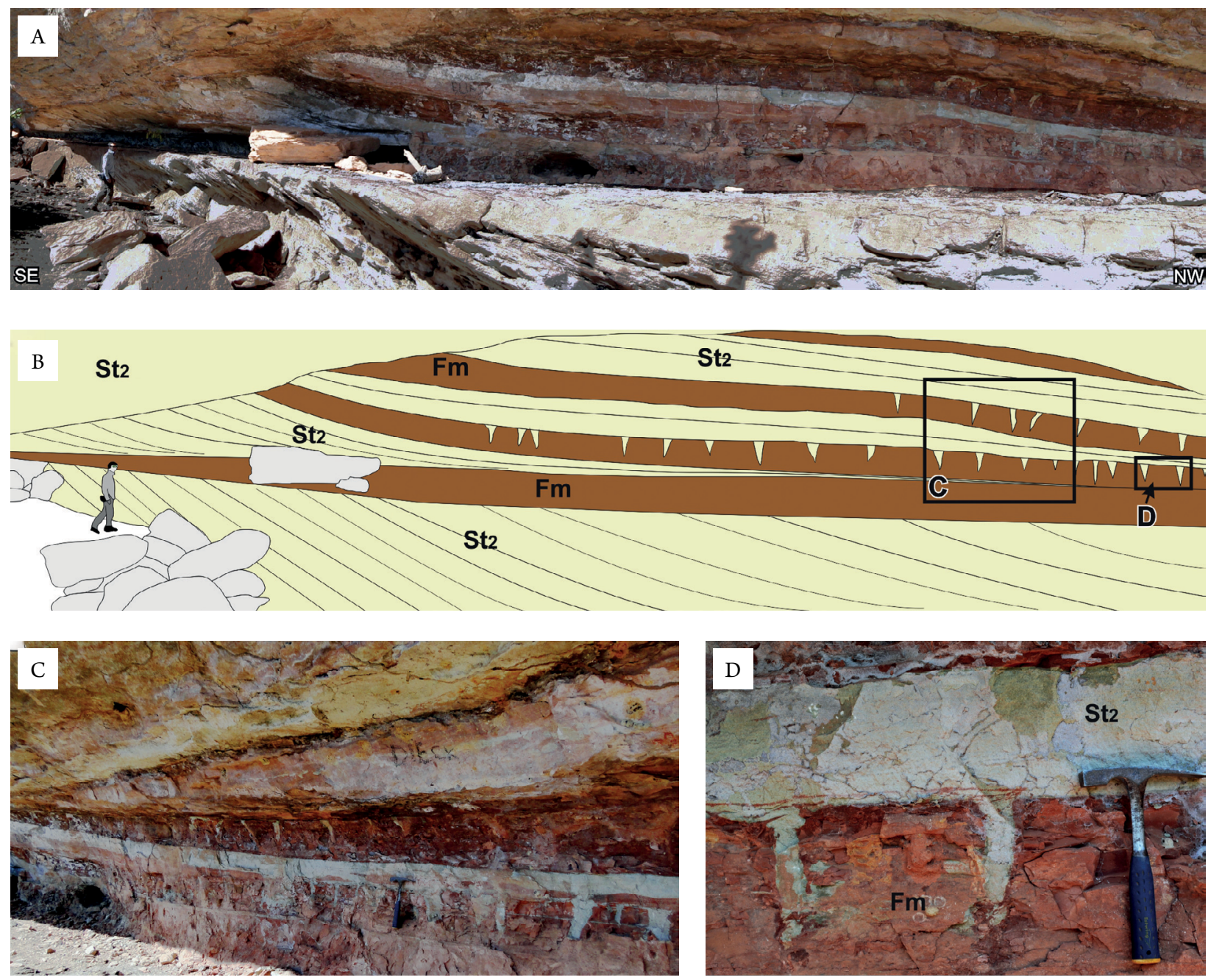

Figure 7. St2 dune facies migrating into interdune area. (A-B) Metric-scale trough cross-stratified sandstone interbedded with mudstones of Fm facies; (C-D) Decimeter- scale desiccation cracks on the top of mudstones record dried pools or playa lakes. Scale at A-B is 1.75-m-high; hammers at C-D are 25-cm-long.
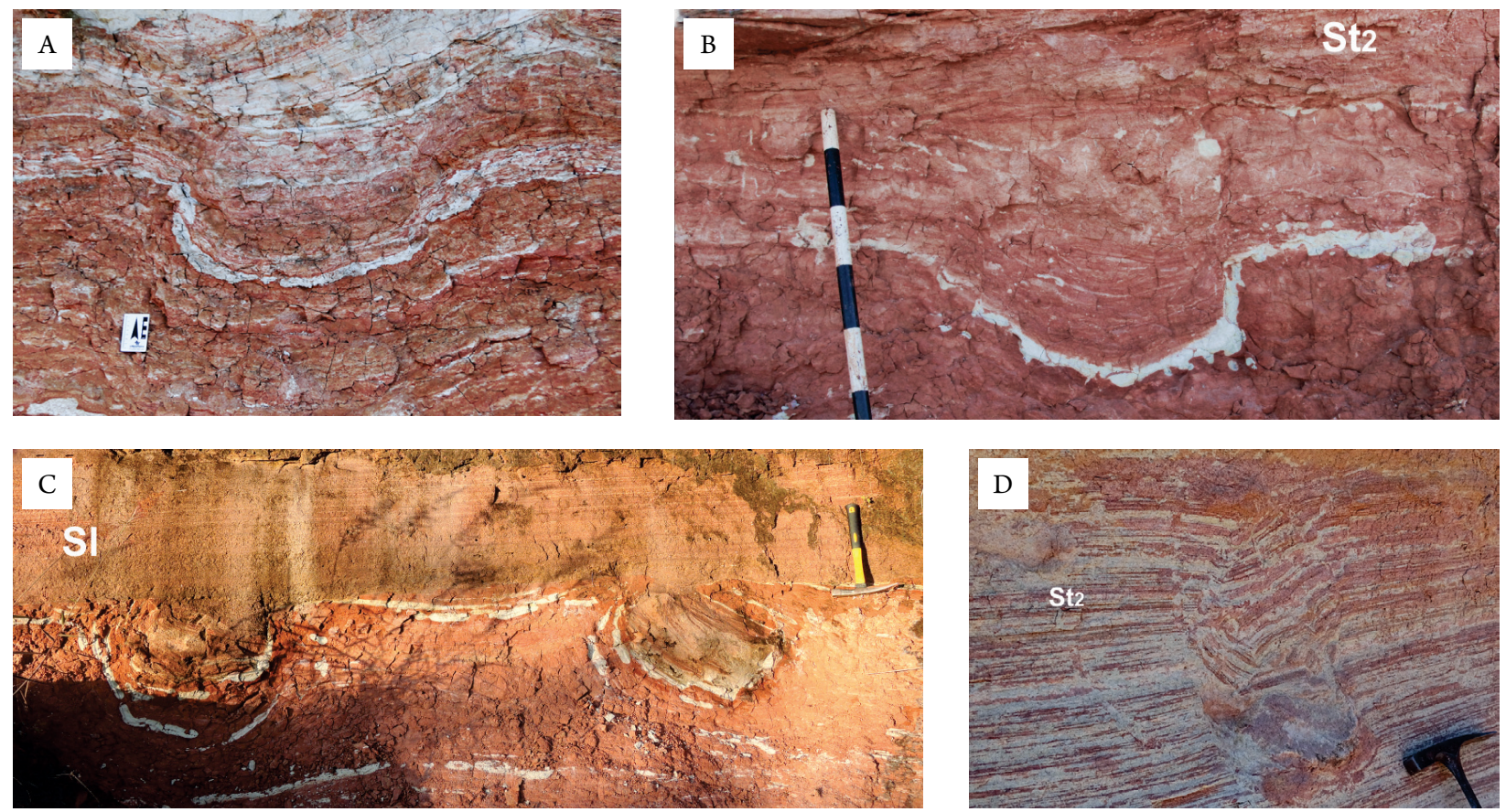

Figure 8. Decimeter-scale concave-upward and asymmetric soft-sediment deformation structures interpreted as footprints and undertracks of the wet eolian system. Soft-sediment deformation and associated micro-faults in wet interdune facies (A and B), in the interdune-dune contact (C), and in dune foresets (D). Scale in A is 8-cm-long; stripes of the scale are 10-cm-long each; hammers in C-D are 25-cm-long. 
which are a representation of wet substrates periodically submitted to subaerial exposure (Buatois and Mángano 2002). The occurrence and preservation of the putative sauropod tracks also requires wet substrates (Laporte and Behrensmeyer 1980, Sung Paik et al. 2001). Paleosols with nodules and carbonate concretions record periods of more pronounced aridity (Wright and Tucker 1991, Retallack 2001), whereas root traces indicate the presence of vegetation. Poorly developed paleosols at the top of the eolian sets the partial stabilization of dunes due to the vegetation (sensu Lancaster 1995, Fig. 9C).

A hypothesized environmental scenario is presented in Figure 9, which illustrates depositional landforms, lithofacies, and sedimentary structures. The presence of subaqueous mega-ripples (facies St1; Figs. 9A-B), interbedded with muddy (facies Fl, Fm and H; Fig. 9B) deposits, suggests the appearance of alluvial settings in the interdunes associated with periodic extreme rain events and water table fluctuations. Thus, the interdunes would vary from wet to damp (Kocurek 1981).
Sustained high-water table reduces eolian deflation, enhancing the preservation of wet interdunes. The described stacking pattern of dune and interdune deposits points toward a continuous relative rise in the water table along the geologic time (Kocurek 1996), preserving the sedimentary succession recorded in the Lower Unit of Três Barras Formation. This continuous rise of the water table resulted in stabilization of dunes and interdunes, and development of the laterally continuous paleosol horizon on the top of the lower stratigraphic unit. The purple color of the paleosol, the presence of mottling and the type of bioturbation suggest development under reducing and hydromorphic conditions. The lack of clear organization in horizons suggests that pedogenesis was concomitant with sediment supply by winds. The constant sediment input did not allow the development of mature paleosols, instead generating cumulic- (sensu Fedoroff et al.2010) or cumulative-type soils (sensu Kraus 1999). Therefore, accumulation and preservation was the result from a conjugation of emplacement into the saturated zone (relative rise in the water table) and stabilization by vegetation cover.
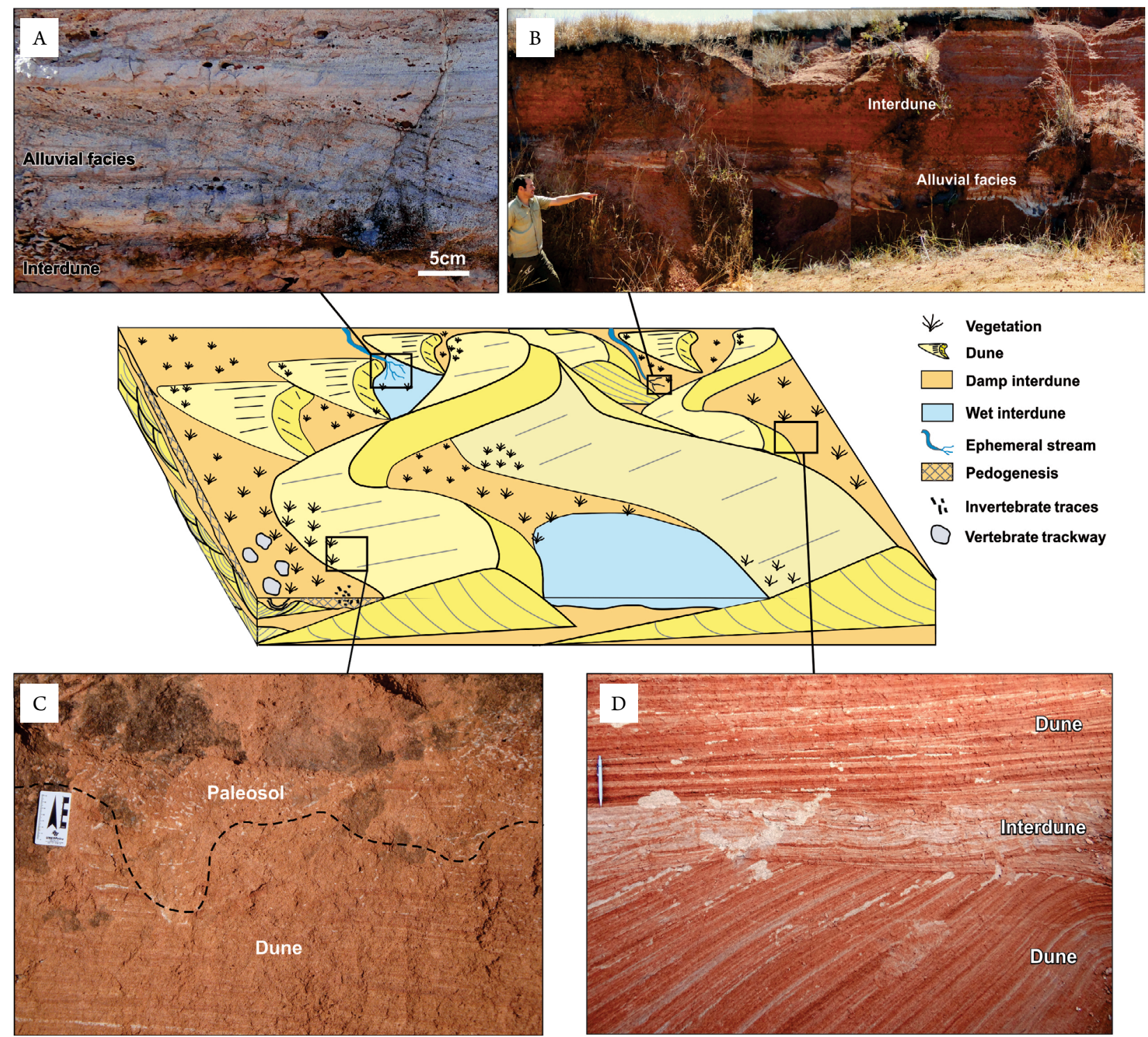

Figure 9. Wet eolian system environmental model including depositional landforms and facies. (A-B) Alluvial facies of ephemeral streams comprising cross-bedded sandstones with rip-up clasts (St1) associated with interdune facies; (C) Thin paleosols developed on eolian dune substrate; (D) Interbedded dune and interdune deposits. Scale in C is 8-cm-long; pencil in D is 15-cm-long. 


\section{UPPER UNIT}

The Upper Unit is about 100-m-thick and overlaps the Sanfranciscana Basin margins, resting directly on the Precambrian metamorphic and magmatic rocks from the basement. The sandstones of Upper Unit are less cemented than the Lower Unit deposits and texturally well sorted, being mainly composed of rounded quartz grains (Figs. 6C-6D).

The paleocurrents derived from down-dip direction of foresets of eolian dune facies $\left(\mathrm{St}_{2}\right.$ and $\mathrm{Sp}$ ) confirm dune migration and sediment transport towards south and southwest (Fig. 4).

\section{Facies association}

The Upper Unit is almost exclusively composed of a succession of sandstones with large-scale trough crossbedding (facies $\mathrm{St}_{2}$; Fig. 10C) and sandstones with large-scale (up to $15 \mathrm{~m}$ ) planar cross-stratification (facies Sp) (Fig. 10A). Sp facies can be attributed to large eolian dunes with well-developed avalanche faces characterized by grain flow processes (Hunter 1977, Kocurek and Dott 1981). These dunes could be transverse, indicating a high sedimentation rate (Wasson and Hyde 1983, Lancaster 1995), or sinuous-crested, which is so large that the strata truncation is not observable in the outcrop scale. In both cases, this facies is associated with huge eolian supply. Bioturbation and pedogenesis are almost absent in all deposits of this unit.

In the uppermost part of the Upper Eolian system, a unique $\sim 10$-m-thick bed of sandstone with deformational structures (Sd) can be tracked laterally for hundreds of meters. These deposits are constituted by deformed beds bounded by non-deformed beds. The sandstones are strongly affected by soft-sediment deformation, producing the convolute bedding and folds that are characteristics of the Sd facies (Figs. 10D-10E). This deformation was generated by liquefaction or fluidization (sensu Lowe 1975), two mechanisms grouped into the general liquidization term (Allen 1984). Pillar structures are present locally and reveal upward-moving of fluidized sands,
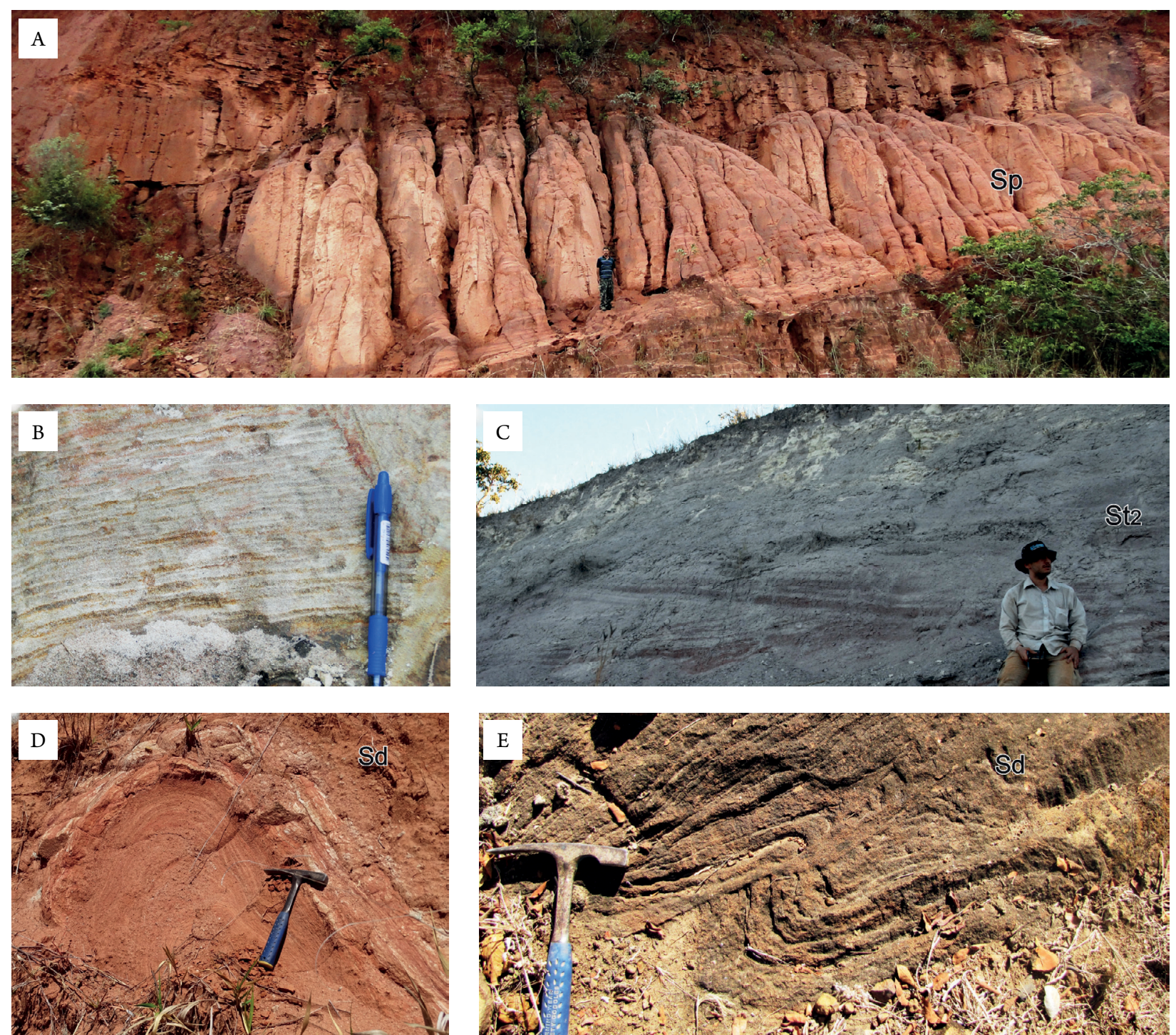

Figure 10. Sedimentary facies of the upper unit of Três Barras Formation. (A) Large-scale planar cross-bedded sandstone (Sp); (B) Grainflow lenses with inverse grading; (C) Medium-scale trough cross-bedded sandstone (St2); (D-E) Soft-sediment deformation structures in sandstones (Sd). Pencil in B is 15-cm-long; hammers in D-E are 25-cm-long. 
dewatering and vertical fluid escape. In some cases, the high liquidization degree completely obliterated the original sedimentary structures of deposits, and the sandstones deposits became structureless.

The concordant contact with the overlying volcanic rocks of Mata da Corda Group is demonstrated by the presence of lapilli and volcanic bombs, with sizes up to $3 \mathrm{~m}$, associated with cross-bedded ( $\mathrm{Sp}$ and $\mathrm{St}_{2}$ facies) and sandstones with deformational structures (Sd facies). The proportion of volcanic fragments within the sandstones is greater near the contact between Três Barras Formation and the overlying Mata da Corda Group (Fig. 11).

\section{Dry eolian system}

As described, the facies associations of the Lower and Upper stratigraphic units of Três Barras Formation reveal two distinct eolian systems in the southern part of the Sanfranciscana Basin.

The predominance of large-scale dunes ( $\mathrm{St}_{2}$ and $\mathrm{Sp}$ facies), without interdunes, strongly suggests deposition in a dry eolian system for the upper stratigraphic unit. This interpretation is reinforced by the scarcity of bioturbation and pedogenetic features, and lack of interbedded alluvial deposits. According to Kocurek and Havholm (1993), dry interdunes accumulations are uncommon in the geological record.

The monotonous succession of the Upper Unit is punctuated by intervals characterized by intense soft-sediment deformation ( $\mathrm{Sd}$ facies), whose occurrence is more common towards the top. Soft-sediment deformation in eolian sandstones is not a rare phenomenon process and can be triggered by a variety of non-seismic processes, including gravitational instability and overloading mechanisms (Moretti 2000). However, the incidence of these processes requires water-saturated sands, which imply rising of the groundwater table during some periods or ephemeral soaking of surficial deposits just after episodic rains. This does not seem to be consistent with the deposition model for this unit. Thus, the presence of deformed beds bounded by non-deformed layers and the existence of structures produced by liquidization (such as water escape features, pillar structures and sand injections) suggest that the soft-sediment deformation was probably generated by the propagation of seismic waves during earthquakes, in similar way to those described by Moretti (2000), Montenat et al. (2007) and Owen et al. (2011).

Seismicity during sedimentation of this bed is possibly linked to the magmatic event of Mata da Corda volcanism. Metric volcanic bombs within the eolian sandstones (Figs. 11A and 11B) attest the synchronism between deposition of eolian sand dunes and the alkaline effusive and explosive event that generated the overlying volcanic and pyroclastic rocks of Mata da Corda Group (Campos and Dardenne 1997b, Sgarbi et al. 2000).
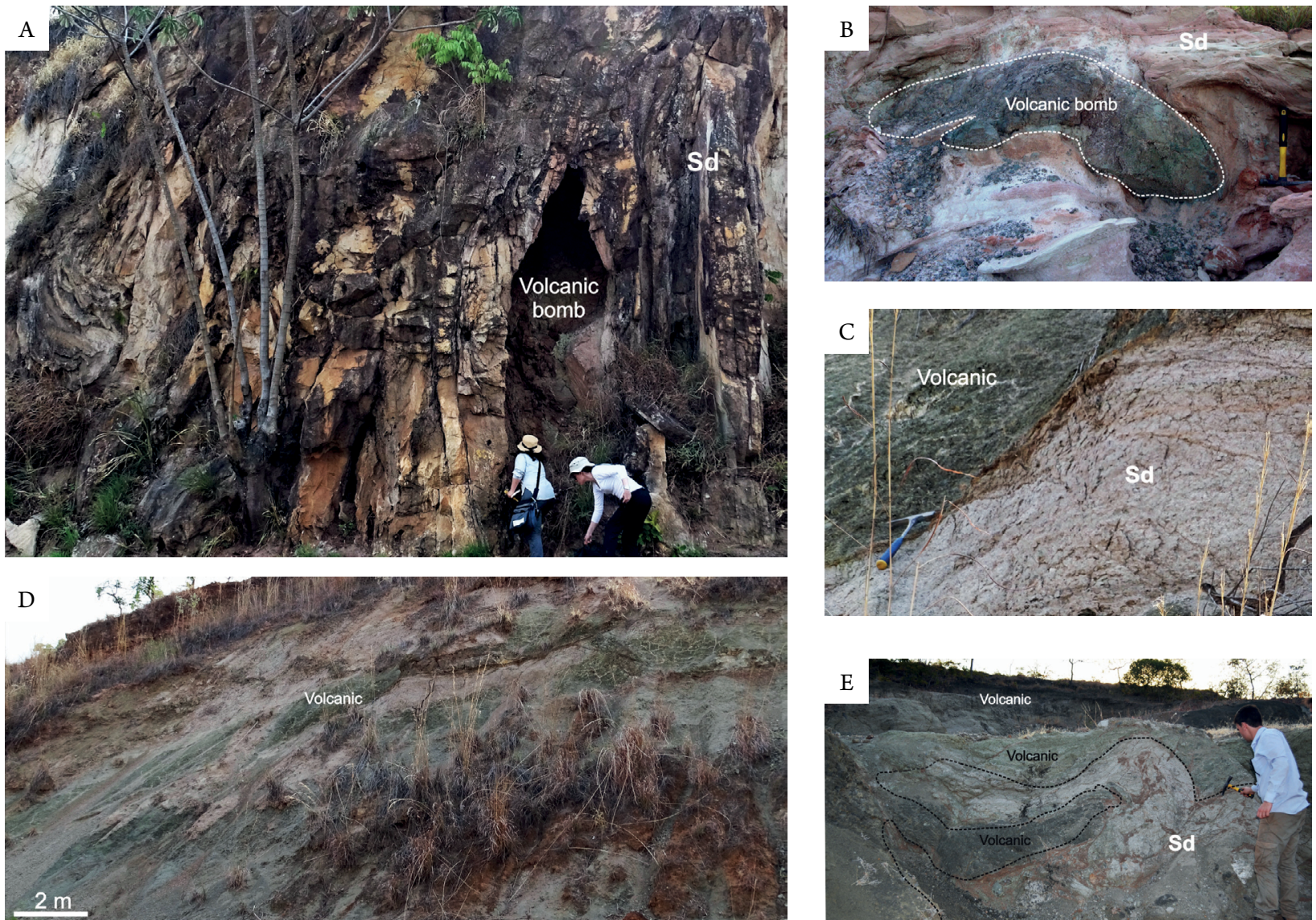

Figure 11. Volcanic bombs and bomb impact structures formed in unconsolidated sandstones by clasts ejected from volcano. (A) Bomb in slumped tilted foresets of large-scale dunes (Sp); (B) Boulder-sized bombs within sandstones with soft-sediment deformation structures; (C-D) Interbedded volcanic rocks and deformed sandstones; (E) Deformed sandstone wrapped in volcanic rocks. Hammers in B-D are 25-cm-long. 


\section{STRATIGRAPHIC IMPLICATIONS}

The existence of a planar erosive surface within Três Barras Formation, separating two contrasting eolian systems is crucial to understand geologic events in the Cretaceous Sanfranciscana Basin. Considering that the surface is erosive and cuts a regional paleosol horizon in the upper portion of the wet eolian system, which can be traced for tens of kilometers and separates two distinct eolian systems, we interpret it as a super bounding surface (Kocurek 1988, Pike and Sweet 2018).

As relicts of dune morphologies are not preserved and the paleosol profiles are truncated by flat erosional surfaces, this paleosol can be interpreted as a stabilized planar super surface, according to the classification of Kocurek and Havholm (1993). It was formed because the potential deflation rate was greater than that of the water table fall, resulting in deflation to the water table level with the surface remaining damp during the super surface formation.

\section{Mid-Cretaceous unconformity}

Super surfaces are not necessarily unconformities, but most of them are associated with unconformities because a gap in the stratigraphic record is involved (Kocurek and Havholm 1993). A crucial question emerges: is there a temporal gap between the two eolian systems? As the eolian facies were not dated themselves, the key to understand the completeness of the stratigraphic record is the relationship with underlying and overlying units.

The Lower Unit facies association of Três Barras Formation overlies conformably the lacustrine (playa lake) deposits of Quiricó Formation, which were dated as Barremian to Aptian based on ostracods (Carmo et al. 2004) and as early Aptian according to its palynologic content (Arai et al. 1995). The interdigitated contact between the two formations suggests an Aptian age for the wet eolian system.

Conversely, the Upper Unit facies are conformably overlain by alkaline volcanic rocks of Mata da Corda Group, which revealed a $\sim 80 \mathrm{Ma}$ U-Th age (Sgarbi et al. 2004). These radiometric data indicate that the age of the uppermost deposits of the dry eolian system is Campanian.

Adopting an Aptian age for the wet eolian system and a Campanian age for the dry eolian system, the hiatus has a magnitude of $\sim 30 \mathrm{Ma}$ (from Albian to Santonian). Even if the Lower Unit sedimentation had been prolonged throughout the Albian and the upper one had started in the Santonian, the hiatus would be as great as $\sim 15 \mathrm{Ma}$. Therefore, the planar erosive contact between the two eolian systems is, in fact, a regional unconformity bounding two different Cretaceous depositional sequences of Sanfranciscana Basin.

The different diagenetic history reinforces the proposed existence of an important temporal gap. Under petrographic microscope, the Upper Cretaceous sandstones are well sorted quartz arenites, texturally and compositionally mature and very porous due to incipient cementation. On the other hand, the lower Cretaceous sandstones present loose grain framework and pervasive cementation by calcium carbonate, suggesting that cementation took place before compaction during eodiagenesis (Fig. 6).

\section{Lower Cretaceous sequence}

The lacustrine facies (Quiricó Formation) and the Lower Unit (defined herein) of Três Barras Formation compose a depositional sequence, of which the lower boundary is the contact with Precambrian metamorphic and magmatic rocks, and the upper boundary is the regional unconformity between the two eolian systems.

The growing proportion of interdune facies reveals an increasing elevation of ground-water table upwards in vertical succession. The presence of the thick paleosol horizon at the top of the wet eolian system marks the end of accumulation. The occurrence of cumulic paleosol suggests a gradual reduction of the sediment supply and an increasing efficiency of pedogenetic processes, which indicate increasing moisture and higher water table (Hendricks 1991, Wojtanowicz 1999).

The paleosol horizon records an important paleoenvironmental change. The eolian system became stabilized due to growing vegetation and progressive decrease of eolian accumulation until the end. A considerable period of high water table was needed to generate the thick and widespread paleosol profile, and the presence of carbonate concentrations around the roots confirm the effectiveness of pedogenetic processes (Retallack 2001, McCarthy and Plint 2013).

The accumulation of dune and interdune deposits in the wet eolian system was a result from continuous sediment supply and water table rise, creating accumulation space for deposition. The maintenance of this balance for a considerable time resulted in the accumulation of at least $70 \mathrm{~m}$ of eolian facies. The preservation of the wet eolian succession corroborates the role of subsidence and burial below the regional water table during the time span before the new sedimentation cycle. Stabilization by vegetation is not enough for preservation that requires the emplacement below the regional base level of erosion (Kocurek and Havholm 1993). It is probable that the groundwater elevation was not associated with an inland effect of a rise in sea level, because the basin was far from the ocean in Cretaceous. The groundwater elevation could, thus, be linked to a climatic change or, more probably, consequence of localized basin subsidence.

\section{Upper Cretaceous sequence}

The Upper Unit (defined herein) of Três Barras Formation belongs to the Upper Cretaceous depositional sequence of the south sector of Sanfranciscana Basin, which includes the volcanic rocks of Mata da Corda Group. Therefore, this is a volcano-sedimentary depositional sequence, whose upper boundary is the regional unconformity on the top of the volcanic rocks. The lower boundary is the unconformity between the two eolian systems where Lower Cretaceous rocks are preserved.

Contact with the overlying volcanic rocks is also a super surface sensu Kocurek and Havholm (1993), it marks the 
end of the eolian accumulation. This contact records the change from eolian environment to a volcanogenic depositional setting without any gap or hiatus. Its conformable character implies that the dry eolian system was preserved due to lava flows and volcanoclastic rocks, similarly to the cases reported for Precambrian of Greenland (Clemmensen 1988) and for the Jurassic/Cretaceous Serra Geral Formation of the Paraná Basin, South Brazil (Almeida 1953, Scherer 2000, Donatti et al. 2001, Assine et al. 2004). Considering a lower nearly flat boundary, the variable thickness of the dry eolian system can be attributed to the erg morphology.

Campanian age is attributed to sandstones due to the concordant contact with the volcanic rocks, but there are no data that allow dating of the sequence beginning, which may have been in the Santonian. High-magnitude earthquake may have accompanied the explosive Mata da Corda volcanism during the deposition of the Upper Unit of Três Barras Formation and is possibly the trigger of the syn-depositional deformations found in these eolian sandstones, similarly to those described by Netoff (2002).

These findings suggest an entirely new vision of the eolian deposits of Sanfranciscana Basin. The recognition of an important unconformity in the middle of Três Barras Formation and the characterization of an Upper Cretaceous (Santonian? to Campanian) depositional sequence implies the necessity of a lithostratigraphic revision and a new interpretation of the basin evolution. We interpret that the eolian deposits of the Upper Unit of Três Barras Formation are correlated and must be considered part of the Urucuia Group that crops out in the north portion of the basin (Urucuia sub-basin). The Urucuia Group is an up to 200-m-thick unit and covers an area of $\sim 76,000 \mathrm{~km}^{2}$, deposited in Upper Cretaceous (Campos and Dardenne 1997a). The group is essentially composed of dune field deposits of dry eolian systems, capped by a section of fluvial deposits of up to 20-m-thick (Spigolon and Alvarenga 2002).

\section{PALEOGEOGRAPHIC AND PALEOCLIMATIC SIGNIFICANCE}

The early Cretaceous has been considered a period of widespread aridity in the equatorial region (Hay and Floegel 2012). The dominance of tropical-equatorial hot arid belts - represented in the Berriasian and Aptian paleogeographic maps of Chumakov et al. (1995), reproduced in Skelton et al. (2003) — and the apparent lack of an equatorial humid zone were explained as a consequence of Supercontinent and Dead Zone effects (Hay and Floegel 2012).

The existence of shallow lakes (Quiricó Formation), filled with deposits of moist eolian systems (Três Barras Formation), associated with paleosols and dinosaur footprints, points to more humid conditions on the southern edge of the arid belt, between $20-30^{\circ}$ latitude at south, west of the trend of the rift lakes that originated to the early Cretaceous basins of the east Atlantic margin of Brazil. The sequence is contemporaneous with the presalt fluvio-lacustrine deposits bearing coquinas (Jiquiá
Stage) of Campos and Santos basins, which correspond to late Barremian to early Aptian international stages (Carvalho et al. 2000, Thompson et al. 2015). In addition to the sedimentary record of Sanfranciscana Basin, many Lower Cretaceous units of Potiguar, Sergipe-Alagoas and Recôncavo-Tucano basins, in Northeastern Brazil, were formed by important river and lake systems (Chang et al. 1992). Thus, the vast arid belt proposed by Chumakov et al. (1995) needs to be better known and outlined in its extent and paleogeography.

The late Cretaceous sequence of Sanfranciscana Basin consists of dry eolian system and superimposed volcanic rocks of Mata da Corda Formation. These volcanic rocks are associated with a regional tectonomagmatic event attributed to the Trindade mantle plume (Guedes et al. 2005). Volcanic and intrusive Campanian magmatic rocks also occur in other onshore areas and in the sedimentary succession of the drift sequences of the offshore basins of Santos (Ar/Ar age $82 \pm 1 \mathrm{Ma}$ - Moreira et al. 2005) and Campos (K/Ar age $81 \pm 5 \mathrm{Ma}$ - Almeida et al. 1996). Uplift and denudation of Southeastern Brazil relief in the Upper Cretaceous (Gallagher and Brown 1999) triggered a reorganization of continental drainage and enhanced sediment supply to Santos (Assine et al. 2008) and Bauru (Batezelli 2015, Fernandes and Ribeiro 2015) basins, during Campanian and Maastrichtian times. Concomitantly, the Alto do Paranaíba uplift separated the Sanfranciscana and Paraná/Bauru basins (Batezelli and Ladeira 2016).

The unconformity between Lower (Barremian/Aptian) and Upper (Santonian?/Campanian) Cretaceous sequences of Sanfranciscana Basin is an important temporal hiatus, spanning at least from the Cenomanian to the Coniacian ( 25 Ma). It encompasses most of the hot greenhouse period (Huber et al. 2018), the warmest interval of the Cretaceous, when temperatures reached the Cretaceous Thermal Maximum, which is an important anoxic event occurred worldwide, while sea level reached the highest level (Haq 2014). During the Early Campanian, by the end of the hot greenhouse period, the Sanfranciscana Basin was overtaken by dunes from the dry eolian system, which dominated the paleogeography, transgressing the original limits of the basin and advancing over Precambrian terrains.

Paleocurrents reveal dominant paleo-winds coming from the northeast quadrant for both the Lower and Upper Cretaceous eolian systems (Fig. 12). This suggests that the continental breakup and drifting apart had little influence on the surface winds in this sector of Gondwana.

During the Aptian, paleo-winds from the eolian system were still related to the Gondwana supercontinent conditions, since the continental break-up was still underway and the Atlantic Ocean had not been developed yet. The absence of contemporaneous units precludes interpretation of wind patterns at surface level, but these were probably similar to those from the Upper Jurassic and Lower Cretaceous, represented by the Botucatu Formation of Paraná Basin (Scherer and Goldberg 2007). The paleocurrents on the 
Upper Cretaceous of Sanfranciscana basin are similar to the ones from Caiuá Formation (Fernandes et al. 2007) from the Paraná/Bauru Basin (Fig. 13B), showing regional sediment transport towards southwest and paleo-winds from northeast. These paleocurrents corroborate an atmospheric circulation pattern with establishment of a high-pressure cell in the Atlantic Ocean, as described by Parrish and Curtis (1982) (Fig. 13C).

Finally, the wet eolian system stabilization by vegetation has occurred during a period of climate amelioration, when the paleosol interval on the top of lower eolian systems was generated. However, there are no direct data to define its timing. We suggest it was formed from the Aptian to the Early Albian, an interval of relatively lower temperature (Huber et al. 1995, Keller 2008) and higher humidity during the Cretaceous in the Southern Hemisphere.

\section{CONCLUSIONS}

The stratigraphic record of Cretaceous Três Barras Formation is a key element to clarify the paleogeography and paleoclimate of South America during and after the breakup of Gondwana and opening of the South Atlantic Ocean. In

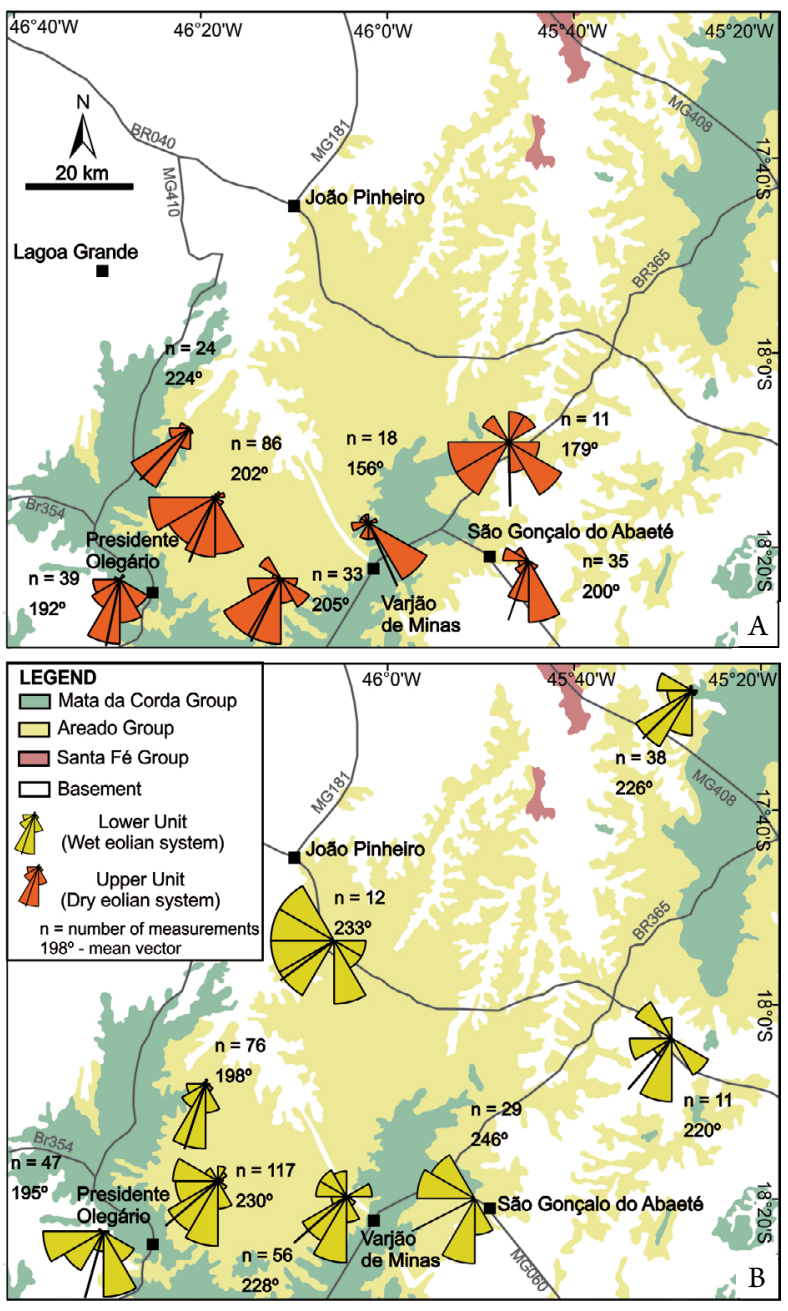

Figure 12. Paleocurrents indicate general dune migration to the southwest during the Cretaceous in the Sanfranciscana Basin. (A) Upper Cretaceous; (B) Lower Cretaceous.
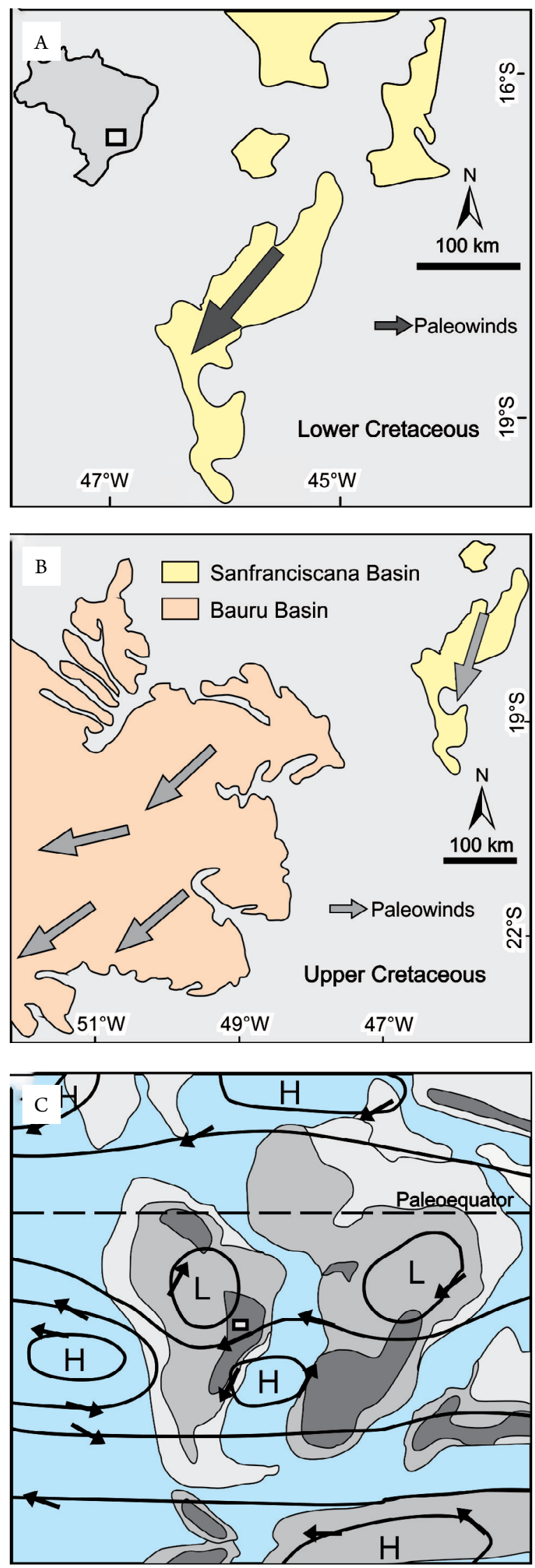

Blue: ocean; light grey: continental shelf; medium grey: lowlands; dark grey: highlands; $\mathrm{H}$ : high pressure zone; L: low pressure zone.

Figure 13. Paleocurrent data and paleo-circulation model for the Upper Cretaceous. (A) Paleocurrents during the Early Cretaceous in Sanfranciscana Basin; (B) Paleocurrents during the Late Cretaceous of Sanfranciscana and Bauru basins (data of the Bauru Basin from Fernandes et al. 2007); (C) Studied area (black polygon) in the context of wind flow according to paleo-circulation model for the Cenomanian proposed by Parrish and Curtis (1982). 
conclusion, by providing a systematic sedimentologic and stratigraphic framework for the unit, with facies, paleosol and paleocurrent data:

- Within Três Barras Formation there is an unconformity separating the sedimentary succession into a lower and an upper stratigraphic unit that record, respectively, wet and dry eolian systems;

- A gap with a time span from at least Cenomanian to Coniacian is proposed for the unconformity, because the eolian facies of the Lower Unit interdigitates with Lower Aptian lacustrine facies, and the Upper Unit is conformably overlain by Campanian volcanic rocks of Mata da Corda Group;

- The Lower Unit (wet eolian system), with Quiricó and Abaeté Formations, compose the Lower Cretaceous depositional sequence of the basin;

- A continuous paleosol horizon present in the upper part of the Lower Unit records vegetation cover, system stabilization, and end of the eolian accumulation, possibly during a period of climate amelioration from the Aptian to the Early Cenomanian;

- The Upper Unit is represented by dune facies of a dry eolian system, here considered the southernmost extension of Urucuia Group, and together with the volcanic and pyroclastic rocks of Mata da Corda Group, composes the Upper Cretaceous depositional sequence of the basin;
- Volcanic bombs found within the dry eolian system are linked to the magmatic event, and soft-sediment deformation structures observed are interpreted as seismically induced, possibly triggered by volcanism and seismicity contemporaneous to sedimentation;

- The dry eolian system preservation was a consequence of burial beneath conformable lava flows, whose lower contact constitutes a super surface representative of the death of the eolian system without any gap in basin infill with volcanogenic rocks;

- Both eolian systems record desertification events in the interior of southeast Brazil during the Cretaceous, and their facies reveal dune migration and sediment transport towards SW and prevailing winds from northeast, validating models of global paleo-circulation during the Cretaceous in Gondwana.

\section{ACKNOWLEDGMENTS}

The authors thank Petrobras (grant 2014/00519-9) for their financial support to the research. L.V. Warren, F.S.B. Ladeira, P.C.F. Giannini and M.L. Assine are fellows of Conselho Nacional de Desenvolvimento Científico e Tecnológico (CNPq). P. C. Mescolotti is grateful for the scholarship from CNPq. We are also grateful to Amanda Santa Catharina for reviewing the manuscript and giving valuable comments.

\section{ARTICLE INFORMATION}

Manuscript ID: 20190057. Received on: 07/12/2019. Approved on: 10/03/2019.

All authors participated in the field campaigns and improved the manuscript through corrections and suggestions. P.C.M. elaborated the manuscript text and its illustrations (figures and table). The manuscript corresponds to part of the results of this author's master's dissertation. Author F.G.V. raised data from paleocurrents and helped prepare the facies table. L.V.W. provided expertise on sedimentary facies and described and interpreted ichnofossils. F.S.L. described and interpreted paleosols. P.C.G. contributed to the writing and interpretation of the sedimentary facies and facies associations and helped with corrections pointed by reviewers. M.L.A is the project's coordinator and assisted with data interpretation and helped write the chapter "Paleogeographic and paleoclimatic significance".

Competing interests: The authors declare no competing interests.

\section{REFERENCES}

Allen J.R.L. 1984. Sedimentary structures their character and physical basis. Development in sedimentology.

Almeida, F.F.M. 1953. Botucatu, a Triassic desert of South America. In 19eme Congrès Géologique International, Alger, 1953. Comptes Rendus, fasc. VII, p. 9-24

Almeida F.F.M., Carneiro C.D.R., Misuzaki A.M.P. 1996. Correlação do magmatismo das bacias da margem continental brasileira com o da áreas emersas adjacentes. Revista Brasileira de Geociências, 26(3):125-138.

Arai M., Dino R., Milhomen P.S., Sgarbi G.N.C. 1995. Micropaleontologia da Formação Areado, Cretáceo da Bacia Sanfranciscana: Estudos de Ostracodes e Palinologia. In: Kellner A.W.A., Viana C.F. (Eds.), XIV Congresso Brasileiro de Paleontologia, Uberaba. Anais..., p. 2-3.

Assine M.L., Carneiro C.D.R., Piranha J.M. 2004. Os paleodesertos Pirambóia e Botucatu. In: Mantesso Neto V., Bartorelli A., Carneiro C.D.R. Brito Neves B.B. (Eds.), Geologia do Continente Sul-Americano: Evolução da Obra de Fernando Flávio Marques de Almeida. São Paulo: Beca, p. 77-92.
Assine M.L., Corrêa F.S., Chang H.K. 2008. Migração de depocentros na Bacia de Santos: importância na exploração de hidrocarbonetos. Revista Brasileira de Geociências, 38(2):111-127.

Atchley S.C., Nordt L.C., Dworki S.I., Cleveland D.M., Mintz J.S., Harlow S.H. 2013. Alluvial stacking pattern analysis and sequence stratigraphy: concepts and case studies. In: Driese S.G., Nordt L.C. (Eds.), New Frontiers in Paleopedology and Terrestrial Paleoclimatology. SEPM, p. 109-129.

Ballén O.A.R., Góes A.M., Negri F.A., Mazivieiro M.V., Teixeira V.Z.S 2013. Aeolian wet system in the sedimentary intertraps successions of Mosquito Formation, Jurassic of the Parnaiba Province, Brazil. Brazilian Journal of Geology, 43(4):695-710. http://doi.org/10.5327/ Z2317-48892013000400009

Batezelli A. 2015. Continental systems tracts of the Brazilian Cretaceous Bauru Basin and their relationship with the tectonic and climatic evolution of South America. Basin Research, 2:1-25. http://dx.doi.org/10.1111/bre.12128 
Batezelli A., Ladeira F.S.B. 2016. Stratigraphic framework and evolution of the Cretaceous continental sequences of the Bauru, Sanfranciscana, and Parecis basins, Brazil. Journal of South American Earth Sciences, 65:1-24. https://doi.org/10.1016/j.jsames.2015.11.005

Bigarella J.J., Salamuni R. 1961. Early Mesozoic wind patterns as suggested by dune bedding in the Botucatú Sandstone of Brazil and Uruguay. Geological Society of America Bulletin, 72(7):1089-1106. https://doi. org/10.1130/0016-7606(1961)72[1089:EMWPAS]2.0.CO;2

Bristow C., Mountney N.P. 2013. Aeolian landscapes, aeolian stratigraphy. In: Shroder J.F. (Ed.), Treatise on Geomorphology. Nova York: Elsevier, p. 246-268.

Bromley R.G. 1996. Trace fossils. Biology, Taphonomy and Applications. Londres: Chapman \& Hall.

BuatoisL.A.,MánganoM.G.2002.Tracefossils from Carboniferousfloodplain deposits in western Argentina: implications for ichnofacies models of continental environments. Palaeogeography, Palaeoclimatology, Palaeoecology, 183(1):71-86. http://dx.doi.org/10.1016/S0031-0182(01)00459-X

Campos J.E.G., Dardenne M.A. 1997a. Estratigrafia e sedimentação da Bacia Sanfranciscana: uma revisão. Revista Brasileira de Geociências, 27(3):269-282.

Campos J.E.G., Dardenne M.A. 1997b. Origem e evolução tectônica da Bacia Sanfranciscana. Revista Brasileira de Geociências, 27(3):283-294.

Carmo D.A., Tomassi H.Z., Oliveira S.B.S.G. 2004. Taxomonia e distribuição estratigráfica dos ostracodes da Formação Quiricó, Grupo Areado (Cretáceo Inferior), Bacia Sanfranciscana, Brasil. Revista Brasileira de Paleontologia, 7(2):139-149.

Carvalho I.S., Kattah S.S. 1998. As Pegadas Fósseis do Paleodeserto da Bacia Sanfranciscana (Jurássico Superior-Cretáceo Inferior, Minas Gerais). Anais da Academia Brasileira de Ciências, 70(1):53-67.

Carvalho M.D., Praça U.M., Silva-Telles Jr. A.C., Jahnert R.J., Dias J.L. 2000. Bioclastic carbonate lacustrine facies models in the Campos Basin (Lower Cretaceous), Brazil. In: Gierlowski-Kordesch E.H., Kelts K.R. (Eds.), Lake basins through space and time. Tulsa: AAPG, p. 245-256.

ChangH.K.,Kowsmann R.O.,FigueiredoA.M.F.,BenderA.A.1992.Tectonics and stratigraphy of the East Brazil Rift system: an overview. Tectonophysics, 213(1-2):97-138. https://doi.org/10.1016/0040-1951(92)90253-3

Chumakov N.M., Zharkov M.A., Herman A.B., Doludenko M.P., Kalandadze N., Lebedev V.A., Ponomarenko A.G., Rautian A.S. 1995. Climatic Belts of the Mid-Cretaceous Time. Stratigraphy and Geological Correlation, 3(3):42-63.

Clemmensen L.B. 1988. Aeolian morphology preserved by lava cover, the Precambrian Mussartut member, Eriksfjord Formation, South Greenland. Bulletin of the Geological Society of Denmark, 37:105-116.

Dentzien-Dias P.C., Schultz C.L., Bertoni-Machado C. 2008. Taphonomy and paleoecology inferences of vertebrate ichnofossils from Guará Formation (Upper Jurassic), Southern Brazil. Journal of South American Earth Science, 25(2):196-202. http://dx.doi.org/10.1016/j.jsames.2007.08.008

Donatti L.M., Sawakuchi A.O., Giannini P.C.F., Fernandes L.A. 2001. The Piramboia-Botucatu succession (Late Permian - Early Cretaceous, Paraná Basin, São Paulo e Paraná States): two contrasting eolian systems. Academia Brasileira de Ciências, 73(3):465. http://dx.doi.org/10.1590/ S0001-37652001000300020

Fedoroff N., Courty M.A., Guo Z. 2010. Palaeosoils and relict soils. In: Stoops G., Marcelino V., Mees F. (Eds.), Interpretation of Micromorphological Features of Soils and Regoliths. New York: Elsevier, p. 623-662.

Fernandes L.A., Castro A.B., Basilici G. 2007. Seismites in continental sand sea deposits of the Late Cretaceous Caiuá Desert, Bauru Basin, Brazil. Sedimentary Geology, 199(1):51-64. http://dx.doi.org/10.1016/j. sedgeo.2005.12.030

Fernandes L.A., Ribeiro C.M.M. 2015. Evolution and palaeoenvironment of the Bauru Basin (Upper Cretaceous, Brazil). Journal of South American Earth Science, 61:71-90. http://dx.doi.org/10.1016/j.jsames.2014.11.007

Fryberger S.G., Schenk C.J. 1988. Pin stripe lamination: A distinctive feature of modern and ancient eolian sediments. Sedimentary Geology, 55(1-2):115. https://doi.org/10.1016/0037-0738(88)90087-5

Gallagher K., Brown R. 1999. The Mesozoic denution history of the Atlantic margins of southern Africa and southeast Brazil and the relationship to offshore sedimentation. Geological Society, London, Special Publications, 153:41-53. https://doi.org/10.1144/GSL.SP.1999.153.01.03

Guedes E., Heilbron M., Vasconcelos P.M., de Morisson Valeriano C., Almeida J.C.H., Teixeira W., Thomaz Filho A. 2005. K-Ar and 40Ar/39Ar ages of dikes emplaced in the onshore basement of the Santos Basin, Resende area, SE Brazil: implications for the south Atlantic opening and Tertiary reactivation volcanic rocks in Brazil through time and different tectonic settings. Journal of South American Earth Sciences, 18(3):371-382. http://dx.doi.org/10.1016/j.jsames.2004.11.008

Haq B.U. 2014. Cretaceous eustasy revisited. Global and Planetary Change, 113:44-58. http://dx.doi.org/10.1016/j.gloplacha.2013.12.007

Hasiotis S.T. 2002. Continental Trace Fossils. SEPM.

Hay W.W., Floegel S. 2012. New thoughts about the Cretaceous climate and oceans. Earth-Science Reviews, 115:262-272. https://cuvpn.colorado. edu/10.1016/,DanaInfo=dx.doi.org+j.earscirev.2012.09.008

Hendricks D.M. 1991. Genesis and classification of arid region soils. In: Skujins J. (Ed.), Semiarid lands and deserts: soil resource and reclamation. Boca Raton: CRC Press.

Howell J., Schwarz E., Spalletti L., Veiga G.D. 2005. The Neuquén Basin: an overview, In: Veiga G.D., Spalletti L., Howell J., Schwarz E. (Eds.), The Neuquén Basin: A Case Study in Sequence Stratigraphy and Basin Dynamics. London: Geological Society of London, p. 1-14.

Huber B.T., Hodell D.A., Hamilton C.P. 1995. Middle-Late Cretaceous climate of the southern high latitudes: stable isotopic evidence for minimal equator-to-pole thermal gradients. Geological Society of America Bulletin, 107(10):1164-1191. https://doi. org/10.1130/0016-7606(1995)107\%3C1164:MLCCOT\%3E2.3.CO;2

Huber B.T., MacLeod K.G., Watkins D.K., Coffin M.F. 2018. The rise and fall of the Cretaceous Hot Greenhouse climate. Global and Planetary Change, 167:1-23. https://doi.org/10.1016/j.gloplacha.2018.04.004

Hunter R.E. 1977. Basic types of stratification in small eolian dunes. Sedimentology, 24(3):361-387.https://doi.org/10.1111/j.1365-3091.1977. tb00128.x

Hunter R.E. 1981. Stratification styles in eolian sandstones: some Pennsylvanian to Jurassic examples from the western interior USA. The Society of Economic Paleontologists and Mineralogists, 31:315-329.

Jones F.H., Scherer C.M.S., Kuchle J. 2016. Facies architecture and stratigraphic evolution of aeolian dune and interdune deposits, Permian Caldeirão Member (Santa Brígida Formation), Brazil. Sedimentary Geology, 337:133-150. http://dx.doi.org/10.1016/j.sedgeo.2016.03.018

Keller G. 2008. Cretaceous climate, volcanism, impacts, and biotic effects. Cretaceous Research, 29(5-6):754-771. http://dx.doi.org/10.1016/j. cretres.2008.05.030

Kocurek G. 1981. Significance of interdune deposits and bounding surfaces in aeolian dune sands. Sedimentology, 28(6):753-780. https://doi. org/10.1111/j.1365-3091.1981.tb01941.x

Kocurek G. 1988. First-order and super bounding surfaces in eolian sequences - bounding surfaces revisited. Sedimentary Geology, 56(14):193-206. https://doi.org/10.1016/0037-0738(88)90054-1

Kocurek G. 1996. Desert eolian systems. In: Reading H.G. (Ed.), Sedimentary environments: processes, facies and stratigraphy. New York: Wiley, p. 125-153.

KocurekG., DottR.H. 1981. Distinctions and uses of stratification types in the interpretation of eolian sand. Journal of Sedimentary Research, 51(2):579-595. https://doi.org/10.1306/212F7CE3-2B24-11D7-8648000102C1865D

Kocurek G., Havholm K.G. 1993. Eolian sequence stratigraphy - a conceptual framework. In: Weimer P., Posamentier H. (Eds.), Siliciclastic sequence stratigraphy - recent developments and applications. Tulsa, AAPG, p. 393-409.

Kocurek G., Nielson J. 1986. Conditions favourable for the formation of warm-climate aeolian sand sheets. Sedimentology, 33(6):795-816. https:// doi.org/10.1111/j.1365-3091.1986.tb00983.x

Kraus M.J. 1999. Paleosols in clastic sedimentary rocks: their geologic applications. Earth-Science Reviews, 47(1-2):41-70. https://doi. org/10.1016/S0012-8252(99)00026-4 
Kuchle J., Scherer C.M.S., Born C.C., Alvarenga R.S., Adegas F. 2011. A contribution to regional stratigraphic correlations of the Afro-Brazilian depression - The Dom João Stage (Brotas Group and equivalent units - Late Jurassic) in Northeastern Brazilian sedimentary basins. Journal of South American Earth Sciences, 31(4):358-371. https://doi.org/10.1016/j. jsames.2011.02.007

Lancaster N. 1995. Geomorphology of desert dunes. London: Routledge.

Langford R.P. 1989. Fluvial-aeolian interactions: Part I, modern systems. Sedimentology, 36(6):1023-1035. https://doi. org/10.1111/j.1365-3091.1989.tb01540.x

Langford R.P., Chan M.A. 1989. Fluvial-aeolian interactions: Part II, ancient systems. Sedimentology, 36(6):1037-1051. http://dx.doi. org/10.1111/j.1365-3091.1989.tb01541.x

Laporte L.F., Behrensmeyer A.K. 1980. Tracks and substrate reworking by terrestrial vertebrates in Quaternary sediments of Kenya. Journal of Sedimentary Research, 50(4):1337-1346. https://doi. org/10.1306/212F7BE9-2B24-11D7-8648000102C1865D

Lima M.R. 1979. Palinologia dos calcários laminados da Formação Areado, Cretáceo de Minas Gerais. In: Simpósio Regional de Geologia, 2., Rio Claro. Anais... p. 203-216.

Lockley M.G. 1991. Tracking dinosaurs. Cambridge: Cambridge University Press, $238 \mathrm{p}$

Lowe D. 1975. Water escape structures in coarse-grained sediments. Sedimentology, 22(2):157-204. http://dx.doi. org/10.1111/j.1365-3091.1975.tb00290.x

McCarthy P.J., Plint A.G. 2013. A pedostratigraphic approach to nonmarine sequence stratigraphy: a three-dimensional paleosol-landscape model from the Cretaceous (Cenomanian) Dunvegan Formation, Alberta and British Columbia, Canada. In: Driese S.G., Nordt L.C. (Eds.), New Frontiers in Paleopedology and Terrestrial Paleoclimatology. Society for Sedimentary Geology, p. 159-178. https://doi.org/10.2110/sepmsp.104.

McKee E.D. 1979. Introduction to a study of global sand seas. In: McKee E.D. (Ed.), A study of global sand seas: U.S. Geological Survey Professional Paper 1052, p. 3-19.

Meyer R. 1987. Paléoalterites et Paléosols: L'empreinte du continent dans les series sédimentaires. France: Editions BRGM.

Montenat C., Barrier P., d'Estevou P.O., Hibsch C. 2007. Seismites: An attempt at critical analysis and classification. Sedimentary Geology, 196(1):530. http://dx.doi.org/10.1016/j.sedgeo.2006.08.004

Moreira J.L.P., Esteves C.A., Rodrigues J.J., Vasconcelos C.S. 2005 Magmatismo, sedimentação e estratigrafia da porção norte da Bacia de Santos. Boletim Geociências da Petrobras, 14(1):161-170.

Moretti M. 2000. Soft-sediment deformation structures interpreted as seismites in middle-late Pleistocene aeolian deposits (Apulian foreland, southern Italy). Sedimentary Geology, 135(1-4):167-179. http://doi. org/10.1016/S0037-0738(00)00070-1

Mountney N.P., Howell J., Flint S., Jerram D. 1999. Climate, sediment supply and tectonics as controls on the deposition and preservation of the aeolian-fluvial Etjo Sandstone Formation, Namibia. Journal of the Geological Society, 156:771-777. https://doi.org/10.1144/gsjgs.156.4.0771

Mountney N.P., Thompson D.B. 2002. Stratigraphic evolution and preservation of aeolian dune and damp/wet interdune strata: an example from the Triassic Helsby Sandstone Formation, Cheshire Basin, UK. Sedimentology, 49(4):805-833. http://dx.doi. org/10.1046/j.1365-3091.2002.00472.x

Netoff D. 2002. Seismogenically induced fluidization of Jurassic erg sands, south-central Utah. Sedimentology, 49(1):65-80. https://doi. org/10.1046/j.1365-3091.2002.00432.x

Nowatzki C.H., Kern H.P. 2000. The Eolianites between Sanga do Cabral and Botucatu Formations in Rio Grande do Sul State, Brazil. Anais da Academia Brasileira da Ciências, 72(2):247-256. http://dx.doi. org/10.1590/S0001-37652000000200010

Owen G., Moretti M., Alfaro P. 2011. Recognising triggers for soft-sediment deformation: Current understanding and future directions. Sedimentary Geology, 235(3-4):133-140. http://dx.doi.org/10.1016/j.sedgeo.2010.12.010

Parrish J.T., Curtis R.L. 1982. Atmospheric circulation, upwelling, and organic-rich rocks in the Mesozoic and Cenozoic eras. Paleogeography,
Palaeoclimatology, Palaeoecology, 40(1-3):31-66. https://doi. org/10.1016/0031-0182(82)90084-0

Pike J.D., Sweet D.E. 2018. Environmental drivers of cyclicity recorded in lower Permian eolian strata, Manitou Springs, Colorado, western United States. Palaeogeography, Palaeoclimatology, Palaeoecology, 499:1-12. http:// dx.doi.org/10.1016/j.palaeo.2018.03.026

Pond S., Lockley M.G., Lockwood J.A.F., Breithaupt B.H., Matthews N.A 2014. Trackings dinosaurs on the Isle of Wight: a review of tracks, sites, and current research. Biological Journal of the Linnean Society, 113(3):737-757. https://doi.org/10.1111/bij.12340

Retallack G.J. 2001. Soils of the Past: an introduction to paleopedology. 2a ed. New Jersey: Blackwell Science.

Scherer C.M.S. 2000. Eolian dunes of the Botucatu Formation (Cretaceous) in southernmost Brazil: morphology and origin. Sedimentary Geology, 137:63-84. https://doi.org/10.1016/S0037-0738(00)00135-4

Scherer C.M.S., Goldberg K. 2007. Palaeowind patterns during the latest Jurassic-earliest Cretaceous in Gondwana: Evidence from aeolian cross-strata of the Botucatu Formation, Brazil. Palaeogeography, Palaeoclimatology, Palaeoecology, 250(1):89-100. https://doi. org/10.1016/j.palaeo.2007.02.018

Scherer C.M.S., Lavina E.L.C. 2005. Sedimentary cycles and facies architecture of aeolian-fluvial strata of the Upper Jurassic Guará Formation, southern Brazil. Sedimentology, 52(6):1323-1341. https://doi. org/10.1111/j.1365-3091.2005.00746.x

Scherer C.M.S., Lavina E.L.C. 2006. Stratigraphic evolution of a fluvial-eolian succession: The example of the Upper Jurassic - Lower Cretaceous Guará and Botucatu formations, Paraná Basin, Southernmost Brazil. Gondwana Research, 9(4):475-484. https://doi.org/10.1016/j. gr.2005.12.002

Schirmer W. 1999. Dune phases and fossil soils in the European sandbelt. In: Schirmer W. (Ed.), Dunes and Fossil Soils. Münster: Lit Verlag, p. 11-42.

Schoeneberger P.J., Wysocki D.A., Benham E.C., Staff S.S. 2012. Field book for describing and sampling soils. Natural Resources Conservation Service, National Soil Survey Center.

Seilacher A. 1967. Bathymetry of trace fossils. Marine Geology, 5(5-6):413 428. https://doi.org/10.1016/0025-3227(67)90051-5

Serviço Geológico do Brasil. 2006. Projeto Brasil ao Milionésimo. CPRM. Available at: http://www.cprm.gov.br/publique/Geologia/GeologiaBasica/Carta-Geologica-do-Brasil-ao-Milionesimo-298.html

Sgarbi G.N.C. 2000. The Cretaceous Sanfranciscan Basin, eastern plateau of Brazil. Revista Brasileira de Geociências, 30(3):450-452.

Sgarbi G.N.C., Sgarbi P., Campos J., Dardenne M.A., Penha U. 2001. Bacia Sanfranciscana: o registro fanerozóico da Bacia do São Francisco. In: Pinto C., Martins-Neto M. (Eds.), Bacia do São Francisco: Geologia e Recursos Naturais. Minas Gerais: Sociedade Brasileira de Geologia, Núcleo de Minas Gerais, p. 93-138.

Sgarbi P.C.B., Gaspari J.C., Valenca J.G. 2000. Brazilian kamafugites. Revista Brasileira de Geociências, 30(3):417-420.

Sgarbi P.C.B., Heaman L.M., Gaspar J.C. 2004. U-Pb perovskite ages for Brazilian kamafugitic rocks: further support for a temporal link to a mantle plume hotspot track. Journal of South American Earth Sciences, 16(8):715 724. http://dx.doi.org/10.1016/j.jsames.2003.12.005

Skelton P., Spicer R.A., Kelley S., Gilmour I. 2003. The Cretaceous world. Cambridge: The Open University and Cambridge University Press.

Spigolon A.L.D., Alvarenga C.J.S. 2002. Fácies e elementos arquiteturais resultantes de mudanças climáticas em um ambiente desértico: Grupo Urucuia (Neocretáceo), Bacia Sanfranciscana. Revista Brasileira de Geociências, 32(4), 579-586.

Strömbäck A., Howell J.A., Veiga G.D. 2005. The transgression of an erg - sedimentation and reworking/soft-sediment deformation of aeolian facies: the Cretaceous Troncoso Member, Neuquén Basin, Argentina. In Veiga G.D., Spalletti L.A., Howell J.A., Schwarz E. (Eds), The Neuquén Basin, Argentina: A Case Study in Sequence Stratigraphy and Basin Dynamics. London: Geological Society London Special Publication, 252, p. 163-183.

Sun J., Muhs D.R. 2007. Dune Fields: Mid-latitudes. In: Elias S.A. (Ed.), Encyclopedia of Quaternary Science. New York: Elsevier, p. 599-607. 
Braz. J. Geol. (2019), 49(3): e20190057

Sung Paik I., Kim H.J., Lee Y.I. 2001. Dinosaur track-bearing deposits in the Cretaceous Jindong Formation, Korea: ocorrence, paleoenvironments and preservation. Cretaceous Research, 22(1):79-92. https://doi.org/10.1006/ cres.2000.0241

Taylor A., Goldring R. 1993. Description and analysis of bioturbation and ichnofabric. Journal of the Geological Society, 150(1):141-148. https://doi. org/10.1144/gsigs.150.1.0141

Thompson D.L., Stilwell J.D., Hall M. 2015. Lacustrine carbonate reservoirs from Early Cretaceous rift lakes of Western Gondwana: Pre-Salt coquinas of Brazil and West Africa. Gondwana Research, 28(1):26-51. http://dx.doi. org/10.1016/j.gr.2014.12.005

Thulborn T. 2012. Impact of sauropod dinosaurs on lagoonal substrates in the Broome Sandstone (Lowe Cretaceous), Western Australia. PLoS One, 7(5):e36208. https://doi.org/10.1371/journal.pone.0036208

Veiga G.D., Spalletti L.A. 2007. The Upper Jurassic (Kimmeridgian) fluvialaeolian systems of the southern Neuquén Basin, Argentina. Gondwana Research, 11(3):286-302. https://doi.org/10.1016/j.gr.2006.05.002

Veiga G.D., Spalletti L.A., Flint S. 2002. Aeolian/fluvial interactions and high-resolution sequence stratigraphy of a non-marine lowstand wedge: the Avilé Member of the Agrio Formation (Lower Cretaceous), central Neuquén Basin, Argentina. Sedimentology, 49(5):1001-1019. https://doi. org/10.1046/j.1365-3091.2002.00487.x

Xing L., Li D., Lockley M.G., Marty D., Zhang J., Persons W.S., You H., Peng C., Kümmell S.B. 2015. Dinosaur natural track casts from the Lower Cretaceous Hekou Group in the Lanzhou-Minhe Basin, Gansu, Northwest China: Ichnology, track formation, and distribution. Cretaceous Research, 52:194-205. http://dx.doi.org/10.1016/j.cretres.2014.10.001

Wasson R.J., Hyde R. 1983. Factors determining desert dune type. Nature, 304:337-339. Factors determining desert dune type. Nature

Wojtanowicz J. 1999. Problem of occurrence and age (TL) of inland Plenivistulian dunes in Poland (on the example of Sandomierz Basin). In: Schirmer W. (Ed.), Dunes and fossil soils. Münster: Lit Verlag, p. 43-53.

Wright V.P., Tucker M.E. 1991. Calcretes. Oxford: Blackwell Scientific Publications.

Zaher H., Pol D., Carvalho A.B., Nascimento P.M., Riccomini C., Larson P., JuarezValieri R., Pires-Domingues R., Silva Jr. N.J.D., Campos D.A. 2011. A complete skull of an Early Cretaceous sauropod and the evolution of advanced titanosaurians. Plos One, 6(2):1-10. https://doi.org/10.1371/journal.pone.0016663 